ReVIeW

\title{
AIP and the somatostatin system in pituitary tumours
}

\author{
Alejandro Ibáñez-Costa and Márta Korbonits \\ Centre for Endocrinology, William Harvey Research Institute, Barts and The London School of Medicine, \\ Queen Mary University of London, London, UK
}

Correspondence should be addressed to M Korbonits

Email

m.korbonits@qmul.ac.uk

\begin{abstract}
Classic somatostatin analogues aimed at somatostatin receptor type 2, such as octreotide and lanreotide, represent the mainstay of medical treatment for acromegaly. These agents have the potential to decrease hormone secretion and reduce tumour size. Patients with a germline mutation in the aryl hydrocarbon receptor-interacting protein gene, AIP, develop young-onset acromegaly, poorly responsive to pharmacological therapy. In this review, we summarise the most recent studies on AIP-related pituitary adenomas, paying special attention to the causes of somatostatin resistance; the somatostatin receptor profile including type 2, type 5 and truncated variants; the role of $\mathrm{G}$ proteins in this pathology; the use of first and second generation somatostatin analogues; and the role of ZAC1, a zinc-finger protein with expression linked to AIP in somatotrophinoma models and acting as a key mediator of octreotide response.
\end{abstract}

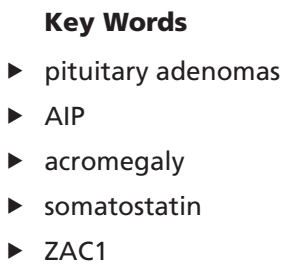

Endocrinology (2017) 235, R101-R116

\section{Introduction}

Pituitary adenomas are usually benign tumours of the anterior pituitary, which represent $15.5 \%$ of intracranial neoplasms (Ostrom et al. 2015). They are frequently associated with severe comorbidities due to mass effect and/or the hormone hypersecretion, such as hypogonadism, hypopituitarism, visual disturbances, hypertension, diabetes, emotional disturbances, changes in appearance, growth abnormalities and many others (Asa \& Ezzat 2002, Aflorei \& Korbonits 2014). These endocrine tumours are unicellular in origin, arising from a monoclonal expansion of a genetically mutated cell (Alexander et al. 1990, Herman et al. 1990, Melmed 1994). The primary initiating cause for pituitary tumourigenesis has been found to be a gain-of-function mutation in the GNAS (Landis et al. 1989) and USP8 (Ma et al. 2015, Reincke et al. 2015) genes in a significant proportion of somatotroph and corticotroph adenomas, while amplification in PIK3CA could be a permissive phenomenon (Finelli et al. 2000,
Lin et al. 2009, Murat et al. 2012). A few cases of corticotroph adenomas have also been identified with germline variants in the CABLES1 gene (HernándezRamírez et al. 2017a).

Several studies using transgenic mouse models have demonstrated that either the inactivation (Jacks et al. 1992, Kiyokawa et al. 1996) or the overexpression (Abbud et al. 2005) of cell cycle regulators may initiate pituitary tumorigenesis. This was supported by the finding that about $80 \%$ of the human pituitary adenomas show at least one alteration in cell cycle regulators (Sapochnik et al. 2016). In the pituitary, classic oncogenes are rarely mutated (Ewing et al. 2007), but a growing set of genes have been identified where loss or gain of function leads to pituitary tumourigenesis (Caimari \& Korbonits 2016). A familial background can be identified in about 5\% of cases either as part of syndromic disease affecting other endocrine organs, including multiple endocrine neoplasia http://joe.endocrinology-journals.org DOI: $10.1530 / \mathrm{JOE}-17-0254$
(C) 2017 Society for Endocrinology Printed in Great Britain
Published by Bioscientifica Ltd 
type 1 and 4, Carney's complex, neurofibromatosis (NF1), DICER1 syndrome and syndromes related to succinate dehydrogenase (SDH) genes or affecting only the pituitary as in familial isolated pituitary adenomas (FIPA) (Beckers \& Daly 2007, Leontiou et al. 2008, Kopczak et al. 2014, Lecoq et al. 2015).

Particularly, FIPA is characterised by the manifestation of pituitary tumours in two or more members of the same family in the absence of other syndromic clinical features. FIPA can also present as simplex disease. It is a heterogeneous condition, which includes patients with low penetrance inactivating germline mutations in the aryl hydrocarbon receptor-interacting protein (AIP) gene (Vierimaa et al. 2006) in 17\% of FIPA families (HernándezRamírez et al. 2015) and patients with the recently described X-linked acrogigantism (XLAG) (Trivellin et al. 2014), which comprise germline or somatic duplications involving GPR101 gene in the Xq26.3 region. Nevertheless, most of FIPA families harbour a currently unknown genetic mutation.

AIP mutation-positive patients are characterised by early onset and usually aggressive growth hormone (GH), prolactin (PRL) or GH-PRL adenomas, rarely other types of pituitary tumours and very rarely concomitant hyperplasia. Patients usually present in the second or third decade (Hernández-Ramírez et al. 2015) and are less responsive to somatostatin analogues (SSA) (Daly et al. 2010). Germline mutations in AIP gene has also been described in sporadic pituitary tumour patients, explained by low penetrance rather than de novo mutations in these families (Leontiou et al. 2008, Jaffrain-Rea et al. 2013, Hernández-Ramírez et al. 2015, Matsumoto et al. 2016). AIP mutation-negative FIPA cases present at a similar age of onset than sporadic pituitary adenoma patients (Hernández-Ramírez et al. 2015).

Patient with XLAG display GH, GH-PRL-secreting adenomas, sometimes with neighbouring hyperplasia or have somatotroph or somatotroph \& lactotroph hyperplasia without an adenoma. Most of the cases result from de novo germline or embryonic mosaic somatic mutations (Beckers et al. 2015, Daly et al. 2016a,b, Iacovazzo et al. 2016b, Trivellin et al. 2016).

In this review, we summarise the most recent studies on AIP-related pituitary adenomas, paying special attention to the causes of the resistance to treatment in acromegaly. For readability, and because often referring to both human, mouse or rat species together, genes/ mRNA (italicised) and proteins (not italicised) will always be capitalised.

\section{AIP: function and malfunction}

AIP encodes a 330 amino-acid $37 \mathrm{kDa}$ protein, which is highly conserved among species and widely distributed in the organism (Trivellin \& Korbonits 2011). AIP is a co-chaperone with an N-terminal immunophilin-like domain (Linnert et al. 2012), which is unable to mediate immunophilin responses (Carver et al. 1998, Laenger et al. 2009) and a highly conserved C-terminal domain with three tetratricopeptide repeat (TPR) motifs and a C-terminal $\alpha-7$ helix (Morgan et al. 2012), which mediate its interactions with a number of partners (Trivellin \& Korbonits 2011). According to experimental data, AIP has a long half-life of $32.7 \mathrm{~h}$ in humans and $30.4 \mathrm{~h}$ in mice, which may indicate that it is an abundant and highly structured protein (Hernández-Ramírez et al. 2016).

AIP is considered to be a tumour suppressor gene in the pituitary, as loss-of-function mutations predispose to pituitary adenomas often with invasive characteristics. Interestingly, sporadic GH-secreting pituitary adenomas with low AIP expression also show markers of increased invasion (Jaffrain-Rea et al. 2009, Kasuki Jomori de Pinho et al. 2011, Kasuki et al. 2012). AIP, a protein with characteristic seven antiparallel alpha helices, has numerous binding partners and loss of some of these interactions may contribute to tumorigenesis.

AIP is a co-chaperone to Hsp90, probably its most important binding partner. As Hsp90 can bind to $60 \%$ of the human kinome and 30\% of E3 ubiquitin ligases (Schopf et al. 2017, Taipale et al. 2010), there are plenty of proteins whose function AIP, a protein with high and ubiquitous expression (Fagerberg et al. 2014), could theoretically influence.

\section{Aryl hydrocarbon receptor (AhR)}

AIP is essential for the stabilization of AhR in the cytoplasm, by the formation of a complex with Hsp90 and p23 proteins, preventing the ubiquitin-mediated degradation of AhR (Kazlauskas et al. 2000); upon ligand binding, AhR experiences a conformational change and is translocated to the nucleus, where it acts as a transcription factor of certain genes, such as P450, a drugmetabolizing enzyme (Fujii-Kuriyama \& Mimura 2005). In pituitary adenomas, reduced AhR was associated with low AIP expression (Jaffrain-Rea et al. 2009), particularly AIP mutation-positive samples showed a frequent loss of cytoplasmic and nuclear AhR, while AIP overexpression was associated to AhR nuclear immunopositivity.

Published by Bioscientifica Ltd. 


\section{Guanine nucleotide-binding proteins (G proteins)}

AIP was found to be associated with $\mathrm{G} \alpha 13, \mathrm{G} \alpha \mathrm{q}$ and possibly regulate the abundance of Goi-2 (Nakata et al. 2009, Tuominen et al. 2015, Ritvonen et al. 2017). These interactions could influence multiple signalling pathways, with the Goi-cAMP pathway being especially relevant regarding somatotroph cells and somatostatin action (see section below).

\section{Cyclic nucleotide phosphodiesterases (PDE)}

A superfamily of enzymes that breakdown cAMP and/or cGMP and therefore regulate their abundance in cells (Beavo 1995) may interact with AIP (HernándezRamírez et al. 2017b). Particularly, AIP was able to reversibly inhibit the enzymatic activity of PDE4A5 (rat counterpart of human PDE4A4) (Bolger et al. 2003). In humans, PDE4A4 and PDE4A8 enzymes were overexpressed in functioning and non-functioning pituitary adenomas in comparison to normal pituitary tissue (Bolger et al. 2016), and in line with this, both PDE4A5 and PDE4A4 were able to interact with wild-type AIP (Leontiou et al. 2008, Bolger et al. 2016), but they did not interact with mutant variants. Moreover, another PDE, PDE2A3 was suggested to interact with AIP inhibiting the nuclear translocation of AhR, and subsequently the transcription of certain genes (de Oliveira et al. 2007), although further data are needed to strengthen this relationship.

\section{Somatostatin and its receptors}

Somatostatin (SST) was isolated in ovine hypothalamus by its ability to inhibit GH secretion (Brazeau et al. 1973). SST is widely distributed throughout the human central nervous system and also in peripheral tissues, where it has a broad range of biological actions including regulation of neurotransmission, inhibition of pituitary and gastrointestinal hormones, pancreatic enzymes and neuropeptides, etc. (Lamberts 1988, Schettini 1991, Martel et al. 2012). SST gene is transcribed to yield the pre-pro somatostatin-encoding mRNA (Shen et al. 1982, Naylor et al. 1983, Shen \& Rutter 1984), which is subsequently translated and the protein is processed to give rise to SST, an active peptide of 28 amino acids (Schally et al. 1980, Brown et al. 1981), which is commonly further processed into a shorter active variant of 14 amino acids, generally named SST-14 or simply SST (Epelbaum 1986, Martel et al. 2012).
SST binds with similar affinity to all its 5 receptor subtypes, named SSTR1-SSTR5, which belong to the seven transmembrane domains (TMD), G proteincoupled receptor superfamily class A (Gahete et al. 2010, Theodoropoulou \& Stalla 2013). SSTRs were characterised, for the first time in pituitary cells, in the rat GH-PRLsecreting GH4C1 cell line (Schonbrunn \& Tashjian 1978), and later, their structure was identified in human, mouse, rat and other species (Patel 1999). SSTRs are encoded by 5 separate genes, which are intronless, share a common YANSCANPVLY motif in the seventh TMD (Olias et al. 2004, Durán-Prado et al. 2009) and give rise to 5 different SSTR variants in humans, including a splice variant of the subtype 2 in mice (Patel 1999, Olias et al. 2004). In addition to the canonical, full-length SSTRs, two novel truncated variants of SSTR5 have been recently identified and characterised in humans, which were termed sst5TMD5 and sst5TMD4, based on the number of TMDs (DuránPrado et al. 2009). Subsequent studies have demonstrated that these receptors are functional, and they show distinct distribution in normal tissues and present unique ligandselective signalling properties and subcellular distribution. Specifically, these receptors are infrequently present in normal tissues, and, while sst5TMD5 is present only in a subset of pituitary adenomas, sst5TMD4 is normally present in pituitary tumours (Durán-Prado et al. 2009, 2010, Luque et al. 2015).

It has been observed that each SSTR subtype specially evokes one or more particular SST actions, and considering that they are usually co-expressed, it has been proposed that the specific effect is determined by the combined effect of quantity and type of SSTR subtype expressed in each cell, and the particular signalling routes activated in response to SST. The binding of a ligand, either endogenous or synthetic, to the different SSTRs exert a conformational change in the receptor leading to activation of $G$ proteins and the subsequent signalling pathways (Eglen 2005, Ben-Shlomo \& Melmed 2010, Shpakov 2012, Theodoropoulou \& Stalla 2013). These pathways can be common among SSTRs, such as cAMP, adenylate cyclase or $\mathrm{Ca} 2+$, or different, considering that most of them are receptor, ligand or dose specific. One example is the apoptotic pathway p53/BAX, which is activated mainly through SSTR3 (Sharma et al. 1996, War et al. 2015). As well as the paradoxically stimulatory effect on GH release observed using very low concentration of SST and cortistatin, an endogenous neuropeptide similar to SST (Ibáñez-Costa et al. 2017), in primate pituitary primary cultures, which is mediated exclusively by SSTR5 through adenylyl cyclase/cAMP/protein kinase A

Published by Bioscientifica Ltd 
and intracellular $\mathrm{Ca}^{2+}$ pathways (Córdoba-Chacón et al. 2012). Thus, the specific cascades triggered are complex as (i) SSTRs frequently co-localise; therefore, the final response will depend on the SSTRs' interaction pattern (Cakir et al. 2010); (ii) they can form homo- and heterodimers (Durán-Prado et al. 2008), not only with each other, but with dopamine receptors, especially the type 2 (DRD2) and $\delta$ - and $\mu$-opioid receptors (OPRD1 and OPRM1) (Rocheville et al. 2000, Pfeiffer et al. 2002, Baragli et al. 2007, Somvanshi \& Kumar 2014); (iii) SSTRs may display a constitutive activity independently from ligand (Acunzo et al. 2008, Ben-Shlomo et al. 2013, Eigler et al. 2014) and (iv) SSTRs, like many other GPCRs, may be regulated by endocytosis, internal trafficking and arrestin-mediated desensitization mechanisms (Hofland \& Lamberts 2003, Tulipano et al. 2004, Gatto et al. 2013a).

\section{Somatostatin analogues and pituitary adenomas}

In addition to, or instead of, surgery, several medical therapeutic approaches are available for functioning pituitary adenomas. Lactotroph tumours are generally very sensitive to dopamine agonists aimed at DRD2, such as cabergoline, decreasing PRL secretion and tumour size, achieving the total remission in a high percentage of patients (Colao \& Savastano 2011).

SST was first discovered due to its role in decreasing the GH release of ovine somatotrophes. Since somatotroph adenomas causing acromegaly and gigantism are characterized by the expression of SSTRs, especially SSTR2 and SSTR5 at the mRNA level (Taboada et al. 2008, Durán-Prado et al. 2009, 2010, Neto et al. 2009, Gatto et al. 2013b) and protein level (Gatto et al. 2013b, Chinezu et al. 2014, Iacovazzo et al. $2016 a$ ), SST was thought to be an important therapeutic agent. However, the clinical usefulness of SST is limited by its short half-life in circulation (less than $3 \mathrm{~min}$ ) (Patel $\&$ Wheatley 1983). Therefore, to overcome this obstacle, synthetic SSAs were developed, such as octreotide and lanreotide, which selectively bind to SSTR2 and can be used to treat neuroendocrine tumours (Bauer et al. 1982, Taylor et al. 1988, Barbieri et al. 2014). In the case of somatotrophinomas, SSAs aimed at SSTR2 are commonly used in the pre- and post-surgical treatment to decrease GH and insulin-like growth factor 1 (IGF1) secretion and tumour size (Melmed 2009, Melmed et al. 2015, Puig Domingo 2015). Additionally, thyrotroph tumours display SSTR2, SSTR3 and SSTR5 (Yoshihara et al. 2007, Gatto et al. 2012) and octreotide is successfully used to treat these tumours, normalizing TSH levels and decreasing tumour size (Caron et al. 2001, Gatto et al. 2012, van Varsseveld et al. 2014).

In a well-conducted study of unselected acromegaly patients treated with octreotide, $25 \%$ of the subjects showed a full clinical benefit: decreased tumour size and normalised both GH and IGF1 levels (Mercado et al. 2007). Therefore, resistance or partial resistance is not so rare, even in patients with high SSTR expression on the tumour after surgery (Colao et al. 2011, Theodoropoulou \& Stalla 2013, Cuevas-Ramos \& Fleseriu 2014). The cause of this lack of response is still unknown. A multi-receptor SSA was developed, pasireotide (Bruns et al. 2002), which can bind SSTR5 (IC50: $0.16 \pm 0.01 \mathrm{nmol} / \mathrm{L}$ ), SSTR2 $(1.0 \pm 0.1 \mathrm{nmol} / \mathrm{L}), \quad$ SSTR $3(1.5 \pm 0.3 \mathrm{nmol} / \mathrm{L})$ and SSTR 1 $(9.3 \pm 0.1 \mathrm{nmol} / \mathrm{L})$ with high affinity, with the hypothesis that simultaneous targeting of more than one SSTR may be more effective in the treatment of patients who are not responsive or who escape from SSTR2 agonist treatment. Another strategy was to develop individual SSTR1, SSTR2 and SSTR5 agonists for potential therapeutic use (Shimon et al. 1997b, Zatelli et al. 2003, 2005, 2006). Somatotroph and lactotroph adenomas frequently have SSTR1, SSTR5 and SSTR2 expression (Hofland et al. 2004, Thodou et al. 2006, Taboada et al. 2007, Fusco et al. 2008, Cuny et al. 2012, Ibáñez-Costa et al. 2016); and corticotroph adenomas typically express SSTR5 (Arnaldi \& Boscaro 2010, Feelders et al. 2010, Colao et al. 2012, 2014, Golor et al. 2012, Lu et al. 2013, Ibáñez-Costa et al. 2016). Classic SSAs aimed to SSTR2 are not effective although corticotroph tumours express high levels of SSTR5 followed by SSTR2 (Hofland et al. 2005, 2010, Batista et al. 2006, de Bruin et al. 2009b, Tateno et al. 2009, Lupp et al. 2012, van der Pas et al. 2013, Ibáñez-Costa et al. 2016), probably, at least partly, because high levels of glucocorticoids decrease SSTR2 levels (de Bruin et al. 2009a). Several studies focused on the role of SSA on gonadotrophderived tumours, particularly on non-functioning pituitary adenomas, tumours with gonadotroph origin but without hormone hypersecretion. These studies have shown that SSTR2-aimed SSAs are usually ineffective (Kopczak et al. 2014, Peverelli et al. 2015), although there is high expression of SSTR3 and SSTR2 and lower expression of SSTR5 (Taboada et al. 2007, Zatelli et al. 2007, Florio et al. 2008, Tateno et al. 2009, Hofland et al. 2010, Lee et al. 2015, Ibáñez-Costa et al. 2016). An in vitro study which used individual and combined SSTR 
agonists suggested that SSTR1 agonists might be useful (Zatelli et al. 2004), and moreover, that pasireotide may reduce cell viability in vitro via the inhibition of VEGF (Zatelli et al. 2007). Indeed, the use of pasireotide was proposed for non-functioning pituitary adenoma patients (Colao et al. 2008), as it has been reflected in two clinical trials (NCT01620138 and NCT01283542; https://clinicaltrials.gov).

\section{The use of somatostatin analogues for acromegaly treatment}

The clinical use and efficacy of SSA in acromegaly patients has been established (Oberg \& Lamberts 2016); however, the intracellular signalling pathways activated and the precise mechanism of effect is still debated.

Some of the approaches used cell lines, either pituitaryderived from murine models, such as GH3, GC, GH4C1 or other cell types, such as CHO-K1 or HEK-293. The responses are variable depending on cell lines as they may miss some key components of SST pathway. For example, GH3 cells do not always express all SSTRs, sometimes not even SSTR2 (Garcia \& Myers 1994, Kim et al. 2005) or p27kip in the case of GH3 or GC cells (Qian et al. 2000, Martín-Rodriguez et al. 2015), p27kip being an effector of certain antiproliferative SST-mediated responses (Pages et al. 1999, Hubina et al. 2006, Grant et al. 2008, Zhou et al. 2012, Aoki et al. 2014, KiseljakVassiliades et al. 2015).

Primary cultures of adenomas derived from acromegaly patients are valuable tools to assess SSA response. Samples from clinically responsive patients show better in vitro response than clinically partially responsive patients (Shimon et al. 1997b, Hofland et al. 2004, Murray et al. 2004, Jaquet et al. 2005b, Ibáñez-Costa et al. 2016). The use of specific individual agonists for each SSTR, either peptidic (Shimon et al. 1997a) or nonpeptidic (Rohrer et al. 1998) molecules, has provided key information on the control of the regulation of pituitary hormones secretion in the pituitary. Particularly, in somatotrophinomas, the use of SSTR2 and/or SSTR5 agonists was able to decrease GH release (Shimon et al. 1997b, Danila et al. 2001, Saveanu et al. 2001, 2002, 2006, Jaquet et al. 2005a,b, Zatelli et al. 2005, Peverelli et al. 2013), nevertheless, the simultaneous activation of SSTR2 and SSTR5 did not always show a greater effect on GH release than the single activation of the receptors (Shimon et al. 1997b, Zatelli et al. 2005). In octreotide- and lanreotide- resistant somatotrophinomas, an SSTR1-aimed analogue was able to inhibit GH secretion in vitro (Matrone et al. 2004). In mixed GH-PRL-secreting adenomas, the use of SSTR5-aimed analogues alone (Zatelli et al. 2005, Gruszka et al. 2012) or in combination with SSTR2 agonists (Fusco et al. 2008), were able to decrease prolactin secretion.

Pasireotide is able to decrease GH secretion and alter other functional endpoints in somatotrophinoma cell cultures (Murray et al. 2004, Ibáñez-Costa et al. 2016, Gatto et al. 2017).

In vitro and in vivo studies provided a list of parameters which allows to predict SSA responsiveness of somatotrophinomas, such as receptor expression, GNAS mutation, granulation pattern or MRI characteristics.

\section{Somatostatin receptors}

SSTR2 SSTR2 mRNA expression, and/or SSTR2/SSTR5 ratio, has been directly correlated with a reduction in GH/IGF1 levels and tumour size after surgery using SSTR2-aimed drugs (Taboada et al. 2008, Neto et al. 2009). SSTR2, but not SSTR5 expression, is associated with acute response to octreotide (Gatto et al. 2013b). High SSTR2 immunoreactivity was associated with good response to SSA (Ferone et al. 2008, Fougner et al. 2008, CasarBorota et al. 2013, Wildemberg et al. 2013, Iacovazzo et al . 2016a). A recent study showed that SSTR2 mRNA levels positively correlated to $\mathrm{GH}$ reduction in vitro in response to octreotide, and a trend in response to pasireotide (Gatto et al. 2017). Somatotrophinomas presenting lower SSTR2 mRNA levels and a lower SSTR2/SSTR5 mRNA ratio showed a better response to pasireotide compared to octreotide.

SSTR5 Although SSTR5 is broadly expressed in somatotrophinomas, few data are available from human studies on responsiveness to compounds activating SSTR5, probably due to the recent introduction of pasireotide. The first such study on acromegaly patients resistant to octreotide showed that the expression of SSTR5 may predict responsiveness to pasireotide treatment; the study observed that patients lacking SSTR5 immunoreactivity in their adenoma sample were resistant to pasireotide, but cases with a high SSTR5 staining score had a better IGF1 response (Iacovazzo et al. 2016a). Interestingly, some differences were observed between the actions of octreotide and pasireotide on gene expression regulation when (c) 2017 Society for Endocrinology Printed in Great Britain
Published by Bioscientifica Ltd 
tested on primary culture of human somatotrophinomas: both octreotide and pasireotide decreased GH mRNA, but only pasireotide was able to alter SSTR2 and SSTR5 gene expression, it decreased SSTR 2 and moderately augmented SSTR5 expression. This could potentially contribute to enhance in vivo response to pasireotide (Ibáñez-Costa et al. 2016). Further studies are needed to clarify the effect on first and second generation SSAs on SSTR expression.

SSTR5 truncated variants The presence of sst5TMD4 is inversely correlated to the anti-secretory effect of octreotide in vitro (Durán-Prado et al. 2010) and in vivo (Durán-Prado et al. 2010, Luque et al. 2015).

\section{GNAS mutation}

The recurrent somatic mutations in GNAS gene coding for the $\alpha$-subunit of the stimulatory G protein Gs, commonly named gsp mutation, have been associated with particular clinical characteristics: smaller and less invading densely granulated tumours, normally appearing in older patients (Landis et al. 1990, Spada et al. 1990, Faglia et al. 1996, Yang et al. 1996, Barlier et al. 1998, Kim et al. 2001, Freda et al. 2007). The implication of gsp mutation in SSA response has been widely discussed (Larkin et al. 2013); nevertheless, a recent meta-analysis revealed that GNAS-positive patients have an approximately $10 \%$ greater reduction in GH levels in response to an acute octreotide suppression test (Efstathiadou et al. 2015). Additionally, GNAS positive patients show high levels of SSTR2 mRNA (Taboada et al. 2011) and low levels of sst5TMD4 (Luque et al. 2015).

\section{Granulation pattern}

Pituitary adenomas have been classified according to their granulation pattern in electron microscopy analysis as densely or sparsely granulated tumours. Cytokeratin staining is used in clinical practice to characterise densely granulated adenomas having cytokertain staining with perinuclear pattern and sprasely granulated adenomas having dot-like pattern (Obari et al. 2008). Sparsely granulated somatotrophinomas occur in younger patients, are larger and more invasive than densely granulated tumours and typically express SSTR5 but not SSTR2 (Mayr et al. 2013), while densely granulated adenomas present higher levels of SSTR2 and are more responsive to SSA treatment (Obari et al. 2008, Fougner et al. 2012, Kato et al. 2012, Brzana et al. 2013, Larkin et al. 2013).

\section{MRI T2 signal intensity}

Hypointense GH-secreting adenomas on T2-weighted MRI are frequently densely granulated adenomas and are associated with a better response to SSAs (Hagiwara et al. 2003, Puig-Domingo et al. 2010, Heck et al. 2012, 2016). The level of SSTR5, but not SSTR2, is negatively correlated with T2 intensity (Shen et al. 2016). Hypointense adenomas are smaller than hyper- and iso-intense adenomas, presenting less invasion of cavernous sinuses and optic chiasm compression, but show higher IGF1 levels (Potorac et al. 2015).

\section{Epigenetic regulation of AIP in SSA response}

MicroRNAs (miRNAs) are small endogenous non-coding RNA molecules (18-25 nucleotides), which may impair protein expression (Bartel 2004, Gadelha et al. 2013a). miR-107 is overexpressed in somatotrophinomas and non-functioning pituitary adenomas (Trivellin et al. 2012). miR-107 inhibited AIP expression in vitro but there was no correlation between miR-107 expression and AIP expression in human samples. Another miR, miR-34a was highly expressed in pituitary adenomas with lower AIP protein levels than in high AIP expression adenomas (Denes et al. 2015). In vitro, the overexpression of miR-34a induced an inhibition of endogenous AIP in HEK293 and GH3 cell lines; miR-34a levels were inversely correlated with the response to SSA treatment, miR-34a levels were lower in those patients controlled with octreotide LAR than in uncontrolled patients. The role of miRNAs in SSA response needs further investigations.

\section{The role of AIP and ZAC1 in SSA response in somatotrophinomas}

Korbonits and coworkers suggested that AIP has a key role in SSA response (Chahal et al. 2012, Gadelha et al. 2013b). Indeed, most of the patients with AIP mutation-positive somatotroph adenomas are, at least partially, resistant to pharmacological treatment with SSAs; nevertheless, the causes of this resistance are complex and may be related to several intracellular characteristics of the mutant tumoural somatotrophes. AIP mutation-positive patients are less responsive to SSTR2-specific SSAs (Leontiou et al. 
2008, Jaffrain-Rea et al. 2009, Daly et al. 2010, Oriola et al. 2013, Iacovazzo et al. 2016a). The abundance of the receptors may be involved; sporadic GH tumours with low AIP protein expression are less likely to be controlled using octreotide (Kasuki et al. 2012) and present lower SSTR2 and SSTR3 and similar SSTR5 levels than tumours with high AIP protein expression (Iacovazzo et al. 2016a), while AIP mutation-positive tumours presented higher levels of SSTR5 than sporadic patients (Chahal et al. 2012).

AIP mutation-positive somatotroph tumours are frequently sparsely granulated adenomas (Leontiou et al. 2008, Hernández-Ramírez et al. 2015) and sparsely granulated pituitary adenomas are known to have poorer response to SSAs (Fougner et al. 2012, Brzana et al. 2013). Patients with GNAS mutations respond better to SSAs (Efstathiadou et al. 2015), while the presence of AIP and GNAS mutations seems to be mutually exclusive in somatotrophinomas (Hernández-Ramírez et al. 2015). Recent studies performed on human and mouse somatotrophinomas demonstrated that AIP is essential to maintain relatively low levels of cAMP in normal somatotrophes, and the lack of AIP causes an accumulation of cAMP through defective Goi-2 signalling, which leads to a downregulation of phosphorylated extracellular signal-regulated kinases $1 / 2$ (p-ERK1/2) and p-CREB (Tuominen et al. 2015). This point was supported by the fact that low Goi-2 levels were observed in sporadic somatotrophinomas with decreased AIP immunoreactivity, and a positive association between AIP and Goi-2 was found at protein level, which suggests a combined regulation (Ritvonen et al. 2017). AIP expression was associated to higher Gai-2 and lower Ki67. In vitro Gai-3 silencing revealed that AIP deficiency might lead to cAMP accumulation via Goi-3, although its expression at protein level was not affected by the presence or absence of AIP (Tuominen et al. 2015).

AIP seems to be directly involved in SST signalling pathways: it has been observed that octreotide treatment induced an increase in AIP both at mRNA and protein levels in GH3 cell line; furthermore, patients treated preoperatively with lanreotide showed increased AIP immunostaining in the somatotroph adenomas compared to samples from age-, sex- and tumour size-matched acromegaly patients (Chahal et al. 2012, Jaffrain-Rea et al. 2013). A novel mechanism of action of octreotide was described involving PI3K signalling pathway, which results in an increase in the expression of ZAC1, a zinc finger protein that regulates cell cycle progression (Theodoropoulou et al. 2006). In line with this, octreotide treatment increases ZAC1 mRNA expression (Theodoropoulou et al. 2006, Chahal et al. 2012), which may link AIP to the ZAC1-mediated antiproliferative
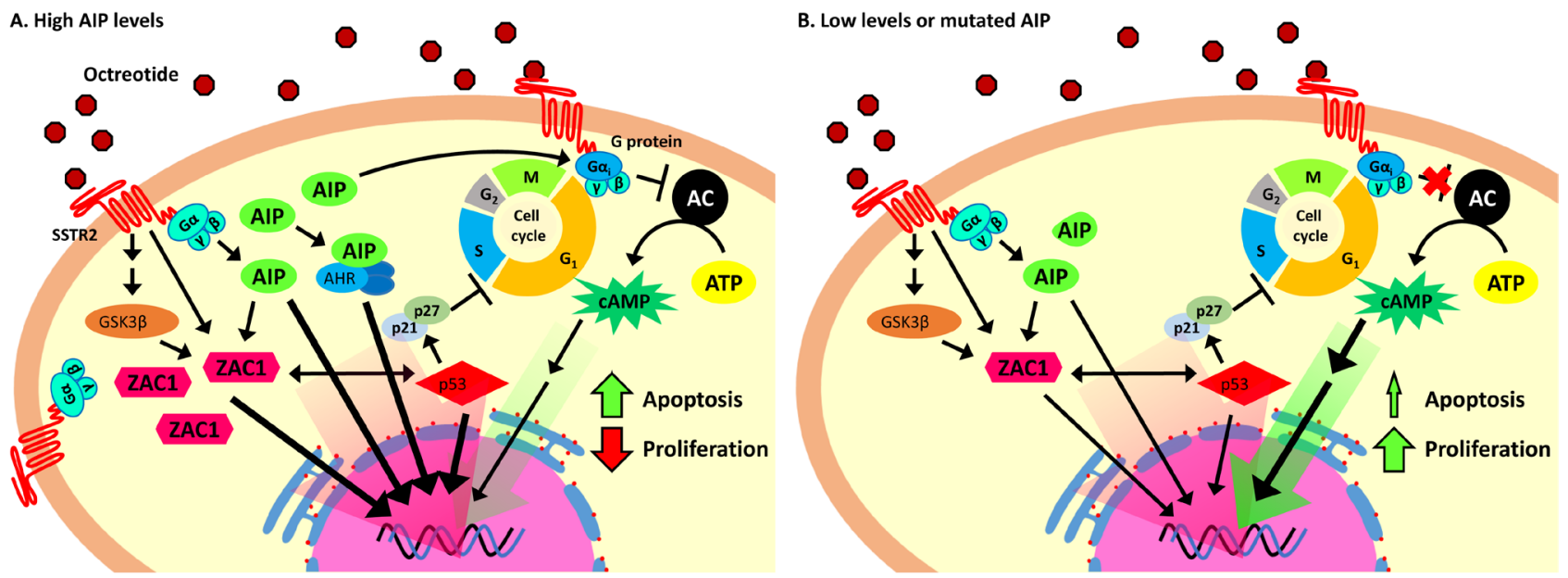

Figure 1

Summary of the proposed model of SSA-AIP-ZAC1 pathway on somatotrophinoma cells. (A) High levels of AIP. AIP (alone or via AHR/ARNT), ZAC1 and p53 directly activate gene transcription; p53 arrests cell cycle, through p21 activation, and increases apoptosis. Octreotide triggers ZAC1/p53 activation through somatostatin receptor 2 (SSTR2) binding and GSK $\beta$ pathway. Octreotide increased AIP and ZAC1 expression. G proteins activate the signalling pathway when SSTR2 binds its ligand, such the inhibition of adenylate cyclase (AC), which reduces CAMP levels. In summary, octreotide decreases cell proliferation (green arrow) and activates the apoptotic pathway (pink arrow) through SSTR2 in somatotrophinomas. (B) Low levels or mutated AIP. ZAC1 expression is decreased when AIP is downregulated, and in AIP mutated patients, presumably disrupting the ZAC1/p53 route. Lower SSTR2 has been reported in some studies in AIP-mutated patients, which may also contribute to the lower effect of SSTR2 aimed SSAs. Lack of AIP reduces the expression of Gai-2 subunit, involved in blocking the AC, which could hinder SST signalling. In summary, the lack of AIP impairs the effect of octreotide, leading to a less activation of apoptotic pathways and increasing the activation of cell proliferation. Arrow-headed lines and bar-headed lines indicate activation and inhibition, respectively. 
response (Fig. 1A). As octreotide treatment caused elevated AIP and heterologous overexpression of wild-type AIP increased ZAC1 expression, while AIP silencing reduced ZAC1 expression (Fig. 1B; Chahal et al. 2012), these all point to an SST-AIP-ZAC1 pathway. In line with this, a recent study revealed that ZAC1 may be a mediator of octreotide antiproliferative effect on gastric cancer cells (Wang et al. 2017).

ZAC1 is encoded by PLAGL1 gene - it is a seven-zinc finger protein functionally related to p53, including tumour suppressor effects through induction of cell cycle arrest at G1 and apoptosis (Spengler et al. 1997, Varrault et al. 1998, Theodoropoulou et al. 2010). PLAGL1 is an imprinted gene highly expressed during embryonic development (Piras et al. 2000, Valente \& Auladell 2001, Valente et al. 2005, Varrault et al. 2006). Postnatally, ZAC1 is highly expressed in the pituitary, mostly in GH and PRL cells in mice, the expression being lower in FSH cells (Pagotto et al. 1999). In humans, GH-, PRL- and ACTH-secreting adenomas express PLAGL1, but its expression in gonadotrophderived tumours is very low (Pagotto et al. 2000, Theodoropoulou et al. 2009). It is remarkable that PLAGL1 gene is located on the chromosome 6q24-25, a region that has been frequently related to loss of heterozygosity events in breast, ovarian and adrenal tumours (Bilanges et al. 1999, Cvetkovic et al. 2004, Lemeta et al. 2004, 2006), and also in non-functioning pituitary adenomas (Pagotto et al. 2000). It has been reported that high ZAC1 immunostaining is associated to a good prognosis in non-functioning pituitary adenomas (Noh et al. 2009), a type of pituitary tumour that display very low ZAC1 expression compared to normal pituitary or somatotrophinomas (Vieria Neto et al. 2013).

\section{Concluding remarks}

In summary, there are several factors that lead to reduced SSA responsiveness: low SSTR2, low SSTR2/SSTR5 ratio, younger age, male gender, high sst5TMD4 expression, hyperintense T2 on MRI, sparsely granulation pattern, low AIP expression, no GNAS mutation, higher basal cAMP levels due to a defective Goi-2 signalling, low ZAC1 levels and presumably a disrupted ZAC1-p53 antiproliferative effect in response to SSAs. The molecular mechanisms connecting all these factors are still unclear and further data and better models are required to fully understand the mechanism of effect of SSAs.
Declaration of interest

The authors declare that there is no conflict of interest that could be perceived as prejudicing the impartiality of this review.

\section{Funding}

The research leading to these results has received funding from the People Programme (Marie Curie Actions) of the European Union's Seventh Framework Programme (FP7/2007-2013) under REA grant agreement $n^{\circ}$ 608765; Rosetrees Trust (M505) and Medical Research Council (MR/ $\mathrm{M} 018539 / 1)$.

\section{References}

Abbud RA, Takumi I, Barker EM, Ren SG, Chen DY, Wawrowsky K \& Melmed S 2005 Early multipotential pituitary focal hyperplasia in the alpha-subunit of glycoprotein hormone-driven pituitary tumor-transforming gene transgenic mice. Molecular Endocrinology 19 1383-1391. (doi:10.1210/me.2004-0403)

Acunzo J, Thirion S, Roche C, Saveanu A, Gunz G, Germanetti AL Couderc B, Cohen R, Figarella-Branger D, Dufour H, et al. 2008 Somatostatin receptor sst2 decreases cell viability and hormonal hypersecretion and reverses octreotide resistance of human pituitary adenomas. Cancer Research 68 10163-10170. (doi:10.1158/0008-5472. CAN-08-1857)

Aflorei ED \& Korbonits M 2014 Epidemiology and etiopathogenesis of pituitary adenomas. Journal of Neuro-Oncology 117 379-394. (doi:10.1007/s11060-013-1354-5)

Alexander JM, Biller BM, Bikkal H, Zervas NT, Arnold A \& Klibanski A 1990 Clinically nonfunctioning pituitary tumors are monoclonal in origin. Journal of Clinical Investigation 86 336-340. (doi:10.1172/ JCI114705)

Aoki T, Motoi F, Sakata N, Naitoh T, Katayose Y, Egawa S, Miyazaki J \& Unno M 2014 Somatostatin analog inhibits the growth of insulinoma cells by p27-mediated G1 cell cycle arrest. Pancreas 43 720-729. (doi:10.1097/MPA.0000000000000128)

Arnaldi G \& Boscaro M 2010 Pasireotide for the treatment of Cushing's disease. Expert Opinion on Investigational Drugs 19 889-898. (doi:10.15 17/13543784.2010.495943)

Asa SL \& Ezzat S 2002 The pathogenesis of pituitary tumours. Nature Reviews: Cancer 2 836-849.

Baragli A, Alturaihi H, Watt HL, Abdallah A \& Kumar U 2007 Heterooligomerization of human dopamine receptor 2 and somatostatin receptor 2 Co-immunoprecipitation and fluorescence resonance energy transfer analysis. Cellular Signalling 19 2304-2316. (doi:10.1016/j.cellsig.2007.07.007)

Barbieri F, Albertelli M, Grillo F, Mohamed A, Saveanu A, Barlier A, Ferone D \& Florio T 2014 Neuroendocrine tumors: insights into innovative therapeutic options and rational development of targeted therapies. Drug Discovery Today 19 458-468. (doi:10.1016/j. drudis.2013.10.015)

Barlier A, Gunz G, Zamora AJ, Morange-Ramos I, Figarella-Branger D, Dufour H, Enjalbert A \& Jaquet P 1998 Pronostic and therapeutic consequences of Gs alpha mutations in somatotroph adenomas. Journal of Clinical Endocrinology and Metabolism 83 1604-1610. (doi:10.1210/jcem.83.5.4797)

Bartel DP 2004 MicroRNAs: genomics, biogenesis, mechanism, and function. Cell 116 281-297. (doi:10.1016/S0092-8674(04)00045-5)

Batista DL, Zhang X, Gejman R, Ansell PJ, Zhou Y, Johnson SA, Swearingen B, Hedley-Whyte ET, Stratakis CA \& Klibanski A 2006 The effects of SOM230 on cell proliferation and adrenocorticotropin secretion in human corticotroph pituitary adenomas. Journal of 
Clinical Endocrinology and Metabolism 91 4482-4488. (doi:10.1210/ jc.2006-1245)

Bauer W, Briner U, Doepfner W, Haller R, Huguenin R, Marbach P, Petcher TJ \& Pless J 1982 SMS 201-995: a very potent and selective octapeptide analogue of somatostatin with prolonged action. Life Sciences 31 1133-1140. (doi:10.1016/0024-3205(82)90087-X)

Beavo JA 1995 Cyclic nucleotide phosphodiesterases: functional implications of multiple isoforms. Physiological Reviews 75 725-748.

Beckers A \& Daly AF 2007 The clinical, pathological, and genetic features of familial isolated pituitary adenomas. European Journal of Endocrinology 157 371-382. (doi:10.1530/EJE-07-0348)

Beckers A, Lodish MB, Trivellin G, Rostomyan L, Lee M, Faucz FR, Yuan B, Choong CS, Caberg JH, Verrua E, et al. 2015 X-linked acrogigantism syndrome: clinical profile and therapeutic responses. Endocrine-Related Cancer 22 353-367. (doi:10.1530/ERC-15-0038)

Ben-Shlomo A \& Melmed S 2010 Pituitary somatostatin receptor signaling. Trends in Endocrinology and Metabolism 21 123-133. (doi:10.1016/j.tem.2009.12.003)

Ben-Shlomo A, Pichurin O, Khalafi R, Zhou C, Chesnokova V, Ren SG, Liu NA \& Melmed S 2013 Constitutive somatostatin receptor subtype 2 activity attenuates GH synthesis. Endocrinology $1542399-2409$. (doi:10.1210/en.2013-1132)

Bilanges B, Varrault A, Basyuk E, Rodriguez C, Mazumdar A, Pantaloni C, Bockaert J, Theillet C, Spengler D \& Journot L 1999 Loss of expression of the candidate tumor suppressor gene ZAC in breast cancer cell lines and primary tumors. Oncogene 18 3979-3988. (doi:10.1038/ sj.onc.1202933)

Bolger GB, Peden AH, Steele MR, MacKenzie C, McEwan DG, Wallace DA, Huston E, Baillie GS \& Houslay MD 2003 Attenuation of the activity of the cAMP-specific phosphodiesterase PDE4A5 by interaction with the immunophilin XAP2. Journal of Biological Chemistry 278 33351-33363. (doi:10.1074/jbc.M303269200)

Bolger GB, Bizzi MF, Pinheiro SV, Trivellin G, Smoot L, Accavitti MA, Korbonits M \& Ribeiro-Oliveira A Jr 2016 cAMP-specific PDE4 phosphodiesterases and AIP in the pathogenesis of pituitary tumors. Endocrine-Related Cancer 23 419-431. (doi:10.1530/ERC-15-0205)

Brazeau P, Vale W, Burgus R, Ling N, Butcher M, Rivier J \& Guillemin R 1973 Hypothalamic polypeptide that inhibits the secretion of immunoreactive pituitary growth hormone. Science 179 77-79. (doi:10.1126/science.179.4068.77)

Brown M, Rivier J \& Vale W 1981 Somatostatin-28: selective action on the pancreatic beta-cell and brain. Endocrinology 108 2391-2396. (doi:10.1210/endo-108-6-2391)

Bruns C, Lewis I, Briner U, Meno-Tetang G \& Weckbecker G 2002 SOM230: a novel somatostatin peptidomimetic with broad somatotropin release inhibiting factor (SRIF) receptor binding and a unique antisecretory profile. European Journal of Endocrinology 146 707-716. (doi:10.1530/eje.0.1460707)

Brzana J, Yedinak CG, Gultekin SH, Delashaw JB \& Fleseriu M 2013 Growth hormone granulation pattern and somatostatin receptor subtype $2 \mathrm{~A}$ correlate with postoperative somatostatin receptor ligand response in acromegaly: a large single center experience. Pituitary 16 490-498. (doi:10.1007/s11102-012-0445-1)

Caimari F \& Korbonits M 2016 Novel genetic causes of pituitary adenomas. Clinical Cancer Research 22 5030-5042. (doi:10.1158/1078 0432.CCR-16-0452)

Cakir M, Dworakowska D \& Grossman A 2010 Somatostatin receptor biology in neuroendocrine and pituitary tumours: part 1 - molecular pathways. Journal of Cellular and Molecular Medicine 14 2570-2584. (doi:10.1111/j.1582-4934.2010.01125.x)

Caron P, Arlot S, Bauters C, Chanson P, Kuhn JM, Pugeat M, Marechaud R, Teutsch C, Vidal E \& Sassano P 2001 Efficacy of the long-acting octreotide formulation (octreotide-LAR) in patients with thyrotropin-secreting pituitary adenomas. Journal of Clinical Endocrinology and Metabolism 86 2849-2853. (doi:10.1210/ jcem.86.6.7593
Carver LA, LaPres JJ, Jain S, Dunham EE \& Bradfield CA 1998 Characterization of the Ah receptor-associated protein, ARA9. Journal of Biological Chemistry 273 33580-33587. (doi:10.1074/ jbc.273.50.33580)

Casar-Borota O, Heck A, Schulz S, Nesland JM, Ramm-Pettersen J, Lekva T, Alafuzoff I \& Bollerslev J 2013 Expression of SSTR2a, but not of SSTRs 1, 3, or 5 in somatotroph adenomas assessed by monoclonal antibodies was reduced by octreotide and correlated with the acute and long-term effects of octreotide. Journal of Clinical Endocrinology and Metabolism 98 E1730-E1739. (doi:10.1210/ jc.2013-2145)

Chahal HS, Trivellin G, Leontiou CA, Alband N, Fowkes RC, Tahir A Igreja SC, Chapple JP, Jordan S, Lupp A, et al. 2012 Somatostatin analogs modulate AIP in somatotroph adenomas: the role of the ZAC1 pathway. Journal of Clinical Endocrinology and Metabolism 97 E1411-E1420. (doi:10.1210/jc.2012-1111)

Chinezu L, Vasiljevic A, Jouanneau E, Francois P, Borda A, Trouillas J \& Raverot G 2014 Expression of somatostatin receptors, SSTR2A and SSTR5, in 108 endocrine pituitary tumors using immunohistochemical detection with new specific monoclonal antibodies. Human Pathology 45 71-77. (doi:10.1016/j. humpath.2013.08.007)

Colao A \& Savastano S 2011 Medical treatment of prolactinomas. Nature Reviews: Endocrinology 7 267-278. (doi:10.1038/nrendo.2011.37)

Colao A, Di Somma C, Pivonello R, Faggiano A, Lombardi G \& Savastano S 2008 Medical therapy for clinically non-functioning pituitary adenomas. Endocrine-Related Cancer 15 905-915. (doi:10.1677/ERC-08-0181)

Colao A, Auriemma RS, Lombardi G \& Pivonello R 2011 Resistance to somatostatin analogs in acromegaly. Endocrine Reviews 32 247-271. (doi:10.1210/er.2010-0002)

Colao A, Petersenn S, Newell-Price J, Findling JW, Gu F, Maldonado M, Schoenherr U, Mills D, Salgado LR, Biller BM, et al. 2012 A 12-month phase 3 study of pasireotide in Cushing's disease. New England Journal of Medicine 366 914-924. (doi:10.1056/NEJMoa1105743)

Colao A, De Block C, Gaztambide MS, Kumar S, Seufert J \& Casanueva FF 2014 Managing hyperglycemia in patients with Cushing's disease treated with pasireotide: medical expert recommendations. Pituitary 17 180-186. (doi:10.1007/s11102-013-0483-3)

Córdoba-Chacón J, Gahete MD, Culler MD, Castaño JP, Kineman RD \& Luque RM 2012 Somatostatin dramatically stimulates growth hormone release from primate somatotrophs acting at low doses via somatostatin receptor 5 and cyclic AMP. Journal of Neuroendocrinology 24 453-463. (doi:10.1111/j.1365-2826.2011.02261.x)

Cuevas-Ramos D \& Fleseriu M 2014 Somatostatin receptor ligands and resistance to treatment in pituitary adenomas. Journal of Molecular Endocrinology 52 R223-R240. (doi:10.1530/JME-14-0011)

Cuny T, Mohamed A, Graillon T, Roche C, Defilles C, Germanetti AL, Couderc B, Figarella-Branger D, Enjalbert A, Barlier A, et al. 2012 Somatostatin receptor sst2 gene transfer in human prolactinomas in vitro: impact on sensitivity to dopamine, somatostatin and dopastatin, in the control of prolactin secretion. Molecular and Cellular Endocrinology 355 106-113. (doi:10.1016/j. mce.2012.01.026)

Cvetkovic D, Pisarcik D, Lee C, Hamilton TC \& Abdollahi A 2004 Altered expression and loss of heterozygosity of the LOT1 gene in ovarian cancer. Gynecologic Oncology 95 449-455. (doi:10.1016/j. ygyno.2004.08.051)

Daly AF, Tichomirowa MA, Petrossians P, Heliovaara E, Jaffrain-Rea ML, Barlier A, Naves LA, Ebeling T, Karhu A, Raappana A, et al. 2010 Clinical characteristics and therapeutic responses in patients with germ-line AIP mutations and pituitary adenomas: an international collaborative study. Journal of Clinical Endocrinology and Metabolism 95 E373-E383. (doi:10.1210/jc.2009-2556)

Daly AF, Lysy PA, Desfilles C, Rostomyan L, Mohamed A, Caberg JH, Raverot V, Castermans E, Marbaix E, Maiter D, et al. $2016 a$ GHRH 
excess and blockade in X-LAG syndrome. Endocrine-Related Cancer 23 161-170. (doi:10.1530/ERC-15-0478)

Daly AF, Yuan B, Fina F, Caberg JH, Trivellin G, Rostomyan L, de Herder WW, Naves LA, Metzger D, Cuny T, et al. 2016b Somatic mosaicism underlies X-linked acrogigantism syndrome in sporadic male subjects. Endocrine-Related Cancer 23 221-233. (doi:10.1530/ERC16-0082)

Danila DC, Haidar JN, Zhang X, Katznelson L, Culler MD \& Klibanski A 2001 Somatostatin receptor-specific analogs: effects on cell proliferation and growth hormone secretion in human somatotroph tumors. Journal of Clinical Endocrinology and Metabolism 86 2976-2981. (doi:10.1210/jcem.86.7.7620)

de Bruin C, Feelders RA, Waaijers AM, van Koetsveld PM, Sprij-Mooij DM, Lamberts SW \& Hofland LJ 2009a Differential regulation of human dopamine D2 and somatostatin receptor subtype expression by glucocorticoids in vitro. Journal of Molecular Endocrinology 42 47-56. (doi:10.1677/JME-08-0110)

de Bruin C, Pereira AM, Feelders RA, Romijn JA, Roelfsema F, Sprij-Mooij DM, van Aken MO, van der Lelij AJ, de Herder WW, Lamberts SW, et al. $2009 \mathrm{~b}$ Coexpression of dopamine and somatostatin receptor subtypes in corticotroph adenomas. Journal of Clinical Endocrinology and Metabolism 94 1118-1124. (doi:10.1210/jc.2008-2101)

de Oliveira SK, Hoffmeister M, Gambaryan S, Muller-Esterl W, Guimaraes JA \& Smolenski AP 2007 Phosphodiesterase 2A forms a complex with the co-chaperone XAP2 and regulates nuclear translocation of the aryl hydrocarbon receptor. Journal of Biological Chemistry $\mathbf{2 8 2}$ 13656-13663. (doi:10.1074/jbc.M610942200)

Denes J, Kasuki L, Trivellin G, Colli LM, Takiya CM, Stiles CE, Barry S, de Castro M, Gadelha MR \& Korbonits M 2015 Regulation of aryl hydrocarbon receptor interacting protein (AIP) protein expression by MiR-34a in sporadic somatotropinomas. PLOS ONE 10 e0117107. (doi:10.1371/journal.pone.0117107)

Durán-Prado M, Malagón MM, Gracia-Navarro F \& Castaño JP 2008 Dimerization of $\mathrm{G}$ protein-coupled receptors: new avenues for somatostatin receptor signalling, control and functioning. Molecular and Cellular Endocrinology 286 63-68. (doi:10.1016/j.mce.2007.12.006)

Durán-Prado M, Gahete MD, Martinez-Fuentes AJ, Luque RM, Quintero A, Webb SM, Benito-Lopez P, Leal A, Schulz S, Gracia-Navarro F, et al. 2009 Identification and characterization of two novel truncated but functional isoforms of the somatostatin receptor subtype 5 differentially present in pituitary tumors. Journal of Clinical Endocrinology and Metabolism 94 2634-2643. (doi:10.1210/ jc.2008-2564)

Durán-Prado M, Saveanu A, Luque RM, Gahete MD, Gracia-Navarro F, Jaquet P, Dufour H, Malagón MM, Culler MD, Barlier A, et al. 2010 A potential inhibitory role for the new truncated variant of somatostatin receptor 5, sst5TMD4, in pituitary adenomas poorly responsive to somatostatin analogs. Journal of Clinical Endocrinology and Metabolism 95 2497-2502. (doi:10.1210/jc.2009-2247)

Efstathiadou ZA, Bargiota A, Chrisoulidou A, Kanakis G, Papanastasiou L, Theodoropoulou A, Tigas SK, Vassiliadi DA, Alevizaki M \& Tsagarakis S 2015 Impact of gsp mutations in somatotroph pituitary adenomas on growth hormone response to somatostatin analogs: a metaanalysis. Pituitary 18 861-867. (doi:10.1007/s11102-015-0662-5)

Eglen RM 2005 Emerging concepts in GPCR function - the influence of cell phenotype on GPCR pharmacology. Proceedings of the Western Pharmacology Society 48 31-34.

Eigler T, Ben-Shlomo A, Zhou C, Khalafi R, Ren SG \& Melmed S 2014 Constitutive somatostatin receptor subtype-3 signaling suppresses growth hormone synthesis. Molecular Endocrinology 28 554-564. (doi:10.1210/me.2013-1327)

Epelbaum J 1986 Somatostatin in the central nervous system: physiology and pathological modifications. Progress in Neurobiology 27 63-100. (doi:10.1016/0301-0082(86)90012-2)

Ewing I, Pedder-Smith S, Franchi G, Ruscica M, Emery M, Vax V, Garcia E, Czirjak S, Hanzely Z, Kola B, et al. 2007 A mutation and expression

http://joe.endocrinology-journals.org

DOI: $10.1530 / \mathrm{JOE}-17-0254$
(C) 2017 Society for Endocrinology Printed in Great Britain analysis of the oncogene BRAF in pituitary adenomas. Clinical Endocrinology 66 348-352. (doi:10.1111/j.1365-2265.2006.02735.x)

Fagerberg L, Hallstrom BM, Oksvold P, Kampf C, Djureinovic D, Odeberg J, Habuka M, Tahmasebpoor S, Danielsson A, Edlund K, et al. 2014 Analysis of the human tissue-specific expression by genomewide integration of transcriptomics and antibody-based proteomics. Molecular and Cellular Proteomics 13 397-406. (doi:10.1074/mcp. M113.035600)

Faglia G, Arosio M \& Spada A 1996 GS protein mutations and pituitary tumors: functional correlates and possible therapeutic implications. Metabolism: Clinical and Experimental 45 117-119. (doi:10.1016/ S0026-0495(96)90103-1)

Feelders RA, de Bruin C, Pereira AM, Romijn JA, Netea-Maier RT, Hermus AR, Zelissen PM, van Heerebeek R, de Jong FH, van der Lely AJ, et al. 2010 Pasireotide alone or with cabergoline and ketoconazole in Cushing's disease. New England Journal of Medicine 362 1846-1848. (doi:10.1056/NEJMc1000094)

Ferone D, de Herder WW, Pivonello R, Kros JM, van Koetsveld PM, de Jong T, Minuto F, Colao A, Lamberts SW \& Hofland LJ 2008 Correlation of in vitro and in vivo somatotropic adenoma responsiveness to somatostatin analogs and dopamine agonists with immunohistochemical evaluation of somatostatin and dopamine receptors and electron microscopy. Journal of Clinical Endocrinology and Metabolism 93 1412-1417. (doi:10.1210/jc.2007-1358)

Finelli P, Giardino D, Rizzi N, Buiatiotis S, Virduci T, Franzin A, Losa M \& Larizza L 2000 Non-random trisomies of chromosomes 5, 8 and 12 in the prolactinoma sub-type of pituitary adenomas: conventional cytogenetics and interphase FISH study. International Journal of Cancer 86 344-350. (doi:10.1002/(SICI)1097-0215(20000501)86:3<344::AIDIJC7>3.0.CO;2-8)

Florio T, Barbieri F, Spaziante R, Zona G, Hofland LJ, van Koetsveld PM, Feelders RA, Stalla GK, Theodoropoulou M, Culler MD, et al. 2008 Efficacy of a dopamine-somatostatin chimeric molecule, BIM-23A760, in the control of cell growth from primary cultures of human nonfunctioning pituitary adenomas: a multi-center study. EndocrineRelated Cancer 15 583-596. (doi:10.1677/ERC-07-0271)

Fougner SL, Borota OC, Berg JP, Hald JK, Ramm-Pettersen J \& Bollerslev J 2008 The clinical response to somatostatin analogues in acromegaly correlates to the somatostatin receptor subtype 2a protein expression of the adenoma. Clinical Endocrinology 68 458-465. (doi:10.1111/ j.1365-2265.2007.03065.x)

Fougner SL, Casar-Borota O, Heck A, Berg JP \& Bollerslev J 2012 Adenoma granulation pattern correlates with clinical variables and effect of somatostatin analogue treatment in a large series of patients with acromegaly. Clinical Endocrinology 76 96-102. (doi:10.1111/j.13652265.2011.04163.x)

Freda PU, Chung WK, Matsuoka N, Walsh JE, Kanibir MN, Kleinman G, Wang Y, Bruce JN \& Post KD 2007 Analysis of GNAS mutations in 60 growth hormone secreting pituitary tumors: correlation with clinical and pathological characteristics and surgical outcome based on highly sensitive GH and IGF-I criteria for remission. Pituitary 10 275-282. (doi:10.1007/s11102-007-0058-2)

Fujii-Kuriyama Y \& Mimura J 2005 Molecular mechanisms of AhR functions in the regulation of cytochrome P450 genes. Biochemical and Biophysical Research Communications 338 311-317. (doi:10.1016/j. bbrc.2005.08.162)

Fusco A, Gunz G, Jaquet P, Dufour H, Germanetti AL, Culler MD, Barlier A \& Saveanu A 2008 Somatostatinergic ligands in dopaminesensitive and -resistant prolactinomas. European Journal of Endocrinology 158 595-603. (doi:10.1530/EJE-07-0806)

Gadelha MR, Kasuki L, Denes J, Trivellin G \& Korbonits M $2013 a$ MicroRNAs: suggested role in pituitary adenoma pathogenesis. Journal of Endocrinological Investigation 36 889-895. (doi:10.1007/ BF03346759)

Gadelha MR, Kasuki L \& Korbonits M 2013b Novel pathway for somatostatin analogs in patients with acromegaly. Trends in 
Endocrinology and Metabolism 24 238-246. (doi:10.1016/j. tem.2012.11.007)

Gahete MD, Durán-Prado M, Luque RM, Martinez-Fuentes AJ, Vazquez-Martinez R, Malagón MM \& Castaño JP 2008 Are somatostatin and cortistatin two siblings in regulating endocrine secretions? In vitro work ahead. Molecular and Cellular Endocrinology 286 128-134. (doi:10.1016/j.mce.2007.11.013)

Gahete MD, Córdoba-Chacón J, Durán-Prado M, Malagón MM, Martínez-Fuentes AJ, Gracia-Navarro F, Luque RM \& Castaño JP 2010 Somatostatin and its receptors from fish to mammals. Annals of the New York Academy of Sciences 1200 43-52. (doi:10.1111/j.17496632.2010.05511.x)

Garcia PD \& Myers RM 1994 Pituitary cell line GH3 expresses two somatostatin receptor subtypes that inhibit adenylyl cyclase: functional expression of rat somatostatin receptor subtypes 1 and 2 in human embryonic kidney 293 cells. Molecular Pharmacology 45 402-409.

Golor G, Hu K, Ruffin M, Buchelt A, Bouillaud E, Wang Y \& Maldonado M 2012 A first-in-man study to evaluate the safety, tolerability, and pharmacokinetics of pasireotide (SOM230), a multireceptor-targeted somatostatin analog, in healthy volunteers. Drug Design, Development and Therapy 6 71-79. (doi:10.2147/DDDT.S29125)

Gatto F, Barbieri F, Gatti M, Wurth R, Schulz S, Ravetti JL, Zona G, Culler MD, Saveanu A, Giusti M, et al. 2012 Balance between somatostatin and $\mathrm{D} 2$ receptor expression drives TSH-secreting adenoma response to somatostatin analogues and dopastatins. Clinical Endocrinology 76 407-414. (doi:10.1111/j.1365-2265.2011.04200.x)

Gatto F, Feelders R, van der Pas R, Kros JM, Dogan F, van Koetsveld PM, van der Lelij AJ, Neggers SJ, Minuto F, de Herder W, et al. 2013a beta-Arrestin 1 and 2 and $\mathrm{G}$ protein-coupled receptor kinase 2 expression in pituitary adenomas: role in the regulation of response to somatostatin analogue treatment in patients with acromegaly. Endocrinology 154 4715-4725. (doi:10.1210/en.2013-1672)

Gatto F, Feelders RA, van der Pas R, Kros JM, Waaijers M, Sprij-Mooij D, Neggers SJ, van der Lelij AJ, Minuto F, Lamberts SW, et al. 2013b Immunoreactivity score using an anti-sst2A receptor monoclonal antibody strongly predicts the biochemical response to adjuvant treatment with somatostatin analogs in acromegaly. Journal of Clinical Endocrinology and Metabolism 98 E66-E71. (doi:10.1210/jc.2012-2609)

Gatto F, Feelders RA, Franck SE, van Koetsveld PM, Dogan F, Kros JM, Neggers S, van der Lely AJ, Lamberts SWJ, Ferone D, et al. 2017 In vitro head-to-head comparison between octreotide and pasireotide in GH-secreting pituitary adenomas. Journal of Clinical Endocrinology and Metabolism 102 2009-2018. (doi:10.1210/jc.2017-00135)

Grant M, Alturaihi H, Jaquet P, Collier B \& Kumar U 2008 Cell growth inhibition and functioning of human somatostatin receptor type 2 are modulated by receptor heterodimerization. Molecular Endocrinology 22 2278-2292. (doi:10.1210/me.2007-0334)

Gruszka A, Culler MD \& Melmed S 2012 Somatostatin analogs and chimeric somatostatin-dopamine molecules differentially regulate human growth hormone and prolactin gene expression and secretion in vitro. Molecular and Cellular Endocrinology 362 104-109. (doi:10.1016/j.mce.2012.05.020)

Hagiwara A, Inoue Y, Wakasa K, Haba T, Tashiro T \& Miyamoto T 2003 Comparison of growth hormone-producing and non-growth hormone-producing pituitary adenomas: imaging characteristics and pathologic correlation. Radiology 228 533-538. (doi:10.1148/ radiol.2282020695)

Heck A, Ringstad G, Fougner SL, Casar-Borota O, Nome T, Ramm-Pettersen J \& Bollerslev J 2012 Intensity of pituitary adenoma on T2-weighted magnetic resonance imaging predicts the response to octreotide treatment in newly diagnosed acromegaly. Clinical Endocrinology 77 72-78. (doi:10.1111/j.1365-2265.2011.04286.x)

Heck A, Emblem KE, Casar-Borota O, Bollerslev J \& Ringstad G 2016 Quantitative analyses of T2-weighted MRI as a potential marker for response to somatostatin analogs in newly diagnosed acromegaly. Endocrine 52 333-343. (doi:10.1007/s12020-015-0766-8)

Herman V, Fagin J, Gonsky R, Kovacs K \& Melmed S 1990 Clonal origin of pituitary adenomas. Journal of Clinical Endocrinology and Metabolism 71 1427-1433. (doi:10.1210/jcem-71-6-1427)

Hernández-Ramírez LC, Gabrovska P, Denes J, Stals K, Trivellin G, Tilley D, Ferrau F, Evanson J, Ellard S, Grossman AB, et al. 2015 Landscape of familial isolated and young-onset pituitary adenomas: prospective diagnosis in AIP mutation carriers. Journal of Clinical Endocrinology and Metabolism 100 E1242-E1254. (doi:10.1210/jc.20151869)

Hernández-Ramírez LC, Martucci F, Morgan RM, Trivellin G, Tilley D, Ramos-Guajardo N, Iacovazzo D, D'Acquisto F, Prodromou C \& Korbonits M 2016 Rapid proteasomal degradation of mutant proteins is the primary mechanism leading to tumorigenesis in patients with missense aip mutations. Journal of Clinical Endocrinology and Metabolism 101 3144-3154. (doi:10.1210/jc.2016-1307)

Hernández-Ramírez LC, Gam R, Valdes N, Lodish MB, Pankratz N, Balsalobre A, Gauthier Y, Faucz FR, Trivellin G, Chittiboina P, et al. $2017 a$ Loss-of-function mutations in the CABLES1 gene are a novel cause of Cushing's disease. Endocrine-Related Cancer 24 379-392. (doi:10.1530/ERC-17-0131)

Hernández-Ramírez LC, Trivellin G \& Stratakis CA 2017b Role of phosphodiesterases on the function of aryl hydrocarbon receptorinteracting protein (AIP) in the pituitary gland and on the evaluation of aip gene variants. Hormone and Metabolic Research 49 286-295. (doi:10.1055/s-0043-104700)

Hofland LJ \& Lamberts SW 2003 The pathophysiological consequences of somatostatin receptor internalization and resistance. Endocrine Reviews 24 28-47. (doi:10.1210/er.2000-0001)

Hofland LJ, van der Hoek J, van Koetsveld PM, de Herder WW, Waaijers M, Sprij-Mooij D, Bruns C, Weckbecker G, Feelders R, van der Lely AJ, et al. 2004 The novel somatostatin analog SOM230 is a potent inhibitor of hormone release by growth hormone- and prolactin-secreting pituitary adenomas in vitro. Journal of Clinical Endocrinology and Metabolism 89 1577-1585. (doi:10.1210/jc.2003031344)

Hofland LJ, van der Hoek J, Feelders R, van Aken MO, van Koetsveld PM, Waaijers M, Sprij-Mooij D, Bruns C, Weckbecker G, de Herder WW, et al. 2005 The multi-ligand somatostatin analogue SOM230 inhibits ACTH secretion by cultured human corticotroph adenomas via somatostatin receptor type 5. European Journal of Endocrinology $\mathbf{1 5 2}$ 645-654. (doi:10.1530/eje.1.01876)

Hofland LJ, Feelders RA, de Herder WW \& Lamberts SW 2010 Pituitary tumours: the sst/D2 receptors as molecular targets. Molecular and Cellular Endocrinology 326 89-98. (doi:10.1016/j.mce.2010.04.020)

Hubina E, Nanzer AM, Hanson MR, Ciccarelli E, Losa M, Gaia D, Papotti M, Terreni MR, Khalaf S, Jordan S, et al. 2006 Somatostatin analogues stimulate p27 expression and inhibit the MAP kinase pathway in pituitary tumours. European Journal of Endocrinology 155 371-379. (doi:10.1530/eje.1.02213)

Iacovazzo D, Carlsen E, Lugli F, Chiloiro S, Piacentini S, Bianchi A, Giampietro A, Mormando M, Clear AJ, Doglietto F, et al. 2016a Factors predicting pasireotide responsiveness in somatotroph pituitary adenomas resistant to first-generation somatostatin analogues: an immunohistochemical study. European Journal of Endocrinology $\mathbf{1 7 4}$ 241-250. (doi:10.1530/EJE-15-0832)

Iacovazzo D, Caswell R, Bunce B, Jose S, Yuan B, Hernández-Ramírez LC, Kapur S, Caimari F, Evanson J, Ferrau F, et al. $2016 b$ Germline or somatic GPR101 duplication leads to X-linked acrogigantism: a clinico-pathological and genetic study. Acta Neuropathologica Communications 4 56. (doi:10.1186/s40478-016-0328-1)

Ibáñez-Costa A, Rivero-Cortés E, Vázquez-Borrego MC, Gahete MD, Jiménez-Reina L, Venegas-Moreno E, de la Riva A, Arráez MA, González-Molero I, Schmid HA, et al. 2016 Octreotide and pasireotide http://joe.endocrinology-journals.org

DOI: $10.1530 / J O E-17-0254$
() 2017 Society for Endocrinology Printed in Great Britain 
(dis)similarly inhibit pituitary tumor cells in vitro. Journal of Endocrinology 231 135-145. (doi:10.1530/JOE-16-0332)

Ibáñez-Costa A, Luque RM \& Castaño JP 2017 Cortistatin: a new link between the growth hormone/prolactin axis, stress, and metabolism. Growth Hormone and IGF Research 33 23-27. (doi:10.1016/j. ghir.2017.01.004)

Jacks T, Fazeli A, Schmitt EM, Bronson RT, Goodell MA \& Weinberg RA 1992 Effects of an Rb mutation in the mouse. Nature 359 295-300. (doi:10.1038/359295a0)

Jaffrain-Rea ML, Angelini M, Gargano D, Tichomirowa MA, Daly AF, Vanbellinghen JF, D'Innocenzo E, Barlier A, Giangaspero F, Esposito V, et al. 2009 Expression of aryl hydrocarbon receptor (AHR) and AHRinteracting protein in pituitary adenomas: pathological and clinical implications. Endocrine-Related Cancer 16 1029-1043. (doi:10.1677/ ERC-09-0094)

Jaffrain-Rea ML, Rotondi S, Turchi A, Occhi G, Barlier A, Peverelli E, Rostomyan L, Defilles C, Angelini M, Oliva MA, et al. 2013 Somatostatin analogues increase AIP expression in somatotropinomas, irrespective of Gsp mutations. Endocrine-Related Cancer 20 753-766. (doi:10.1530/ERC-12-0322)

Jaquet P, Gunz G, Saveanu A, Barlier A, Dufour H, Taylor J, Dong J, Kim S, Moreau JP \& Culler MD 2005a BIM-23A760, a chimeric molecule directed towards somatostatin and dopamine receptors, vs universal somatostatin receptors ligands in GH-secreting pituitary adenomas partial responders to octreotide. Journal of Endocrinological Investigation 28 21-27.

Jaquet P, Gunz G, Saveanu A, Dufour H, Taylor J, Dong J, Kim S, Moreau JP, Enjalbert A \& Culler MD $2005 b$ Efficacy of chimeric molecules directed towards multiple somatostatin and dopamine receptors on inhibition of GH and prolactin secretion from GH-secreting pituitary adenomas classified as partially responsive to somatostatin analog therapy. European Journal of Endocrinology 153 135-141. (doi:10.1530/ eje.1.01950)

Kasuki Jomori de Pinho L, Vieira Neto L, Armondi Wildemberg LE, Gasparetto EL, Marcondes J, de Almeida Nunes B, Takiya CM \& Gadelha MR 2011 Low aryl hydrocarbon receptor-interacting protein expression is a better marker of invasiveness in somatotropinomas than Ki-67 and p53. Neuroendocrinology 94 39-48. (doi:10.1159/000322787)

Kasuki L, Vieira Neto L, Wildemberg LE, Colli LM, de Castro M, Takiya CM \& Gadelha MR 2012 AIP expression in sporadic somatotropinomas is a predictor of the response to octreotide LAR therapy independent of SSTR2 expression. Endocrine-Related Cancer 19 L25-L29. (doi:10.1530/ERC-12-0020)

Kato M, Inoshita N, Sugiyama T, Tani Y, Shichiri M, Sano T, Yamada S \& Hirata Y 2012 Differential expression of genes related to drug responsiveness between sparsely and densely granulated somatotroph adenomas. Endocrine Journal 59 221-228. (doi:10.1507/endocrj.EJ11-0177)

Kazlauskas A, Poellinger L \& Pongratz I 2000 The immunophilin-like protein XAP2 regulates ubiquitination and subcellular localization of the dioxin receptor. Journal of Biological Chemistry 275 41317-41324. (doi:10.1074/jbc.M007765200)

Kim HJ, Kim MS, Park YJ, Kim SW, Park DJ, Park KS, Kim SY, Cho BY, Lee HK, Jung HW, et al. 2001 Prevalence of Gs alpha mutations in Korean patients with pituitary adenomas. Journal of Endocrinology 168 221-226. (doi:10.1677/joe.0.1680221)

Kim E, Sohn S, Lee M, Park C, Jung J \& Park S 2005 Effect of gsp oncogene on somatostatin receptor subtype 1 and 2 mRNA levels in GHRH-responsive GH3 cells. Pituitary 8 155-162. (doi:10.1007/ s11102-005-5245-4)

Kiseljak-Vassiliades K, Xu M, Mills TS, Smith EE, Silveira LJ, Lillehei KO, Kerr JM, Kleinschmidt-DeMasters BK \& Wierman ME 2015 Differential somatostatin receptor (SSTR) 1-5 expression and downstream effectors in histologic subtypes of growth hormone pituitary tumors. Molecular and Cellular Endocrinology 417 73-83. (doi:10.1016/j.mce.2015.09.016)
Kiyokawa H, Kineman RD, Manova-Todorova KO, Soares VC, Hoffman ES, Ono M, Khanam D, Hayday AC, Frohman LA \& Koff A 1996 Enhanced growth of mice lacking the cyclin-dependent kinase inhibitor function of p27(Kip1). Cell 85 721-732. (doi:10.1016/S00928674(00)81238-6)

Kopczak A, Renner U \& Karl Stalla G 2014 Advances in understanding pituitary tumors. F1000 Prime Reports 6 5. (doi:10.12703/P6-5)

Laenger A, Lang-Rollin I, Kozany C, Zschocke J, Zimmermann N, Ruegg J, Holsboer F, Hausch F \& Rein T 2009 XAP2 inhibits glucocorticoid receptor activity in mammalian cells. FEBS Letters 583 1493-1498. (doi:10.1016/j.febslet.2009.03.072)

Lamberts SW 1988 The role of somatostatin in the regulation of anterior pituitary hormone secretion and the use of its analogs in the treatment of human pituitary tumors. Endocrine Reviews 9 417-436. (doi:10.1210/edrv-9-4-417)

Landis CA, Masters SB, Spada A, Pace AM, Bourne HR \& Vallar L 1989 GTPase inhibiting mutations activate the alpha chain of Gs and stimulate adenylyl cyclase in human pituitary tumours. Nature $\mathbf{3 4 0}$ 692-696. (doi:10.1038/340692a0)

Landis CA, Harsh G, Lyons J, Davis RL, McCormick F \& Bourne HR 1990 Clinical characteristics of acromegalic patients whose pituitary tumors contain mutant Gs protein. Journal of Clinical Endocrinology and Metabolism 71 1416-1420. (doi:10.1210/jcem-71-6-1416)

Larkin S, Reddy R, Karavitaki N, Cudlip S, Wass J \& Ansorge O 2013 Granulation pattern, but not GSP or GHR mutation, is associated with clinical characteristics in somatostatin-naive patients with somatotroph adenomas. European Journal of Endocrinology 168 491-499. (doi:10.1530/EJE-12-0864)

Lecoq AL, Kamenicky P, Guiochon-Mantel A \& Chanson P 2015 Genetic mutations in sporadic pituitary adenomas - what to screen for? Nature Reviews: Endocrinology 11 43-54. (doi:10.1038/nrendo.2014.181)

Lee M, Lupp A, Mendoza N, Martin N, Beschorner R, Honegger J, Schlegel J, Shively T, Pulz E, Schulz S, et al. 2015 SSTR3 is a putative target for the medical treatment of gonadotroph adenomas of the pituitary. Endocrine-Related Cancer 22 111-119. (doi:10.1530/ERC-14-0472)

Lemeta S, Pylkkanen L, Sainio M, Niemela M, Saarikoski S, HusgafvelPursiainen K \& Bohling T 2004 Loss of heterozygosity at 6q is frequent and concurrent with $3 p$ loss in sporadic and familial capillary hemangioblastomas. Journal of Neuropathology and Experimental Neurology 63 1072-1079. (doi:10.1093/jnen/63.10.1072)

Lemeta S, Salmenkivi K, Pylkkanen L, Sainio M, Saarikoski ST, Arola J, Heikkila P, Haglund C, Husgafvel-Pursiainen K \& Bohling T 2006 Frequent loss of heterozygosity at 6q in pheochromocytoma. Human Pathology 37 749-754. (doi:10.1016/j. humpath.2006.02.002)

Leontiou CA, Gueorguiev M, van der Spuy J, Quinton R, Lolli F, Hassan S, Chahal HS, Igreja SC, Jordan S, Rowe J, et al. 2008 The role of the aryl hydrocarbon receptor-interacting protein gene in familial and sporadic pituitary adenomas. Journal of Clinical Endocrinology and Metabolism 93 2390-2401. (doi:10.1210/jc.2007-2611)

Lin Y, Jiang X, Shen Y, Li M, Ma H, Xing M \& Lu Y 2009 Frequent mutations and amplifications of the PIK3CA gene in pituitary tumors. Endocrine-Related Cancer 16 301-310. (doi:10.1677/ERC-08-0167)

Linnert M, Haupt K, Lin YJ, Kissing S, Paschke AK, Fischer G, Weiwad M \& Lucke C 2012 NMR assignments of the FKBP-type PPIase domain of the human aryl-hydrocarbon receptor-interacting protein (AIP). Biomolecular NMR Assignments 6 209-212. (doi:10.1007/s12104-0129359-0)

Lu L, Duan L, Jin Z, Lu Z \& Gu F 2013 Effective long-term treatment of Cushing's disease with pasireotide: a case report. Endocrine Practice 19 e92-e96. (doi:10.4158/EP12296.CR)

Lupp A, Nagel F, Doll C, Rocken C, Evert M, Mawrin C, Saeger W \& Schulz S 2012 Reassessment of sst3 somatostatin receptor expression in human normal and neoplastic tissues using the novel rabbit monoclonal antibody UMB-5. Neuroendocrinology 96 301-310. (doi:10.1159/000337659) 
Luque RM, Ibáñez-Costa A, Neto LV, Taboada GF, Hormaechea-Agulla D, Kasuki L, Venegas-Moreno E, Moreno-Carazo A, Gálvez MA, SotoMoreno A, et al. 2015 Truncated somatostatin receptor variant sst5TMD4 confers aggressive features (proliferation, invasion and reduced octreotide response) to somatotropinomas. Cancer Letters 359 299-306. (doi:10.1016/j.canlet.2015.01.037)

Ma ZY, Song ZJ, Chen JH, Wang YF, Li SQ, Zhou LF, Mao Y, Li YM, Hu RG, Zhang ZY, et al. 2015 Recurrent gain-of-function USP8 mutations in Cushing's disease. Cell Research 25 306-317. (doi:10.1038/cr.2015.20)

Martel G, Dutar P, Epelbaum J \& Viollet C 2012 Somatostatinergic systems: an update on brain functions in normal and pathological aging. Frontiers in Endocrinology 3 154. (doi:10.3389/ fendo.2012.00154)

Martín-Rodriguez JF, Muñoz-Bravo JL, Ibáñez-Costa A, Fernández-Maza L, Balcerzyk M, Leal-Campanario R, Luque RM, Castaño JP, VenegasMoreno E, Soto-Moreno A, et al. 2015 Molecular characterization of growth hormone-producing tumors in the GC rat model of acromegaly. Scientific Reports 5 16298. (doi:10.1038/srep16298)

Matrone C, Pivonello R, Colao A, Cappabianca P, Cavallo LM, Del Basso De Caro ML, Taylor JE, Culler MD, Lombardi G, Di Renzo GF, et al. 2004 Expression and function of somatostatin receptor subtype 1 in human growth hormone secreting pituitary tumors deriving from patients partially responsive or resistant to long-term treatment with somatostatin analogs. Neuroendocrinology 79 142-148. (doi:10.1159/000077272)

Matsumoto R, Izawa M, Fukuoka H, Iguchi G, Odake Y, Yoshida K, Bando H, Suda K, Nishizawa H, Takahashi M, et al. 2016 Genetic and clinical characteristics of Japanese patients with sporadic somatotropinoma. Endocrine Journal 63 953-963. (doi:10.1507/ endocrj.EJ16-0075)

Mayr B, Buslei R, Theodoropoulou M, Stalla GK, Buchfelder M \& Schofl C 2013 Molecular and functional properties of densely and sparsely granulated GH-producing pituitary adenomas. European Journal of Endocrinology 169 391-400. (doi:10.1530/EJE-13-0134)

Melmed S 1994 Pituitary neoplasia. Endocrinology and Metabolism Clinics of North America 23 81-92.

Melmed S 2009 Acromegaly pathogenesis and treatment. Journal of Clinical Investigation 119 3189-3202. (doi:10.1172/JCI39375)

Melmed S, Popovic V, Bidlingmaier M, Mercado M, van der Lely AJ, Biermasz N, Bolanowski M, Coculescu M, Schopohl J, Racz K, et al. 2015 Safety and efficacy of oral octreotide in acromegaly: results of a multicenter phase III trial. Journal of Clinical Endocrinology and Metabolism 100 1699-1708. (doi:10.1210/jc.2014-4113)

Mercado M, Borges F, Bouterfa H, Chang TC, Chervin A, Farrall AJ, Patocs A, Petersenn S, Podoba J, Safari M, et al. 2007 A prospective, multicentre study to investigate the efficacy, safety and tolerability of octreotide LAR (long-acting repeatable octreotide) in the primary therapy of patients with acromegaly. Clinical Endocrinology $6 \mathbf{6}$ 859-868. (doi:10.1111/j.1365-2265.2007.02825.x)

Morgan RM, Hernández-Ramírez LC, Trivellin G, Zhou L, Roe SM, Korbonits M \& Prodromou C 2012 Structure of the TPR domain of AIP: lack of client protein interaction with the C-terminal alpha-7 helix of the TPR domain of AIP is sufficient for pituitary adenoma predisposition. PLOS ONE 7 e53339. (doi:10.1371/journal. pone.0053339)

Mori R, Inoshita N, Takahashi-Fujigasaki J, Joki T, Nishioka H, Abe T, Fujii T \& Yamada S 2013 Clinicopathological features of growth hormone-producing pituitary adenomas in 242 acromegaly patients: classification according to hormone production and cytokeratin distribution. ISRN Endocrinology 2013723432. (doi:10.1155/2013/723432)

Murat CB, Braga PB, Fortes MA, Bronstein MD, Correa-Giannella ML \& Giorgi RR 2012 Mutation and genomic amplification of the PIK3CA proto-oncogene in pituitary adenomas. Brazilian Journal of Medical and Biological Research 45 851-855. (doi:10.1590/S0100879X2012007500115)
Murray RD, Kim K, Ren SG, Lewis I, Weckbecker G, Bruns C \& Melmed S 2004 The novel somatostatin ligand (SOM230) regulates human and rat anterior pituitary hormone secretion. Journal of Clinical Endocrinology and Metabolism 89 3027-3032. (doi:10.1210/jc.2003031319)

Nakata A, Urano D, Fujii-Kuriyama Y, Mizuno N, Tago K \& Itoh H 2009 G-protein signalling negatively regulates the stability of aryl hydrocarbon receptor. EMBO Reports 10 622-628. (doi:10.1038/ embor.2009.35)

Naylor SL, Sakaguchi AY, Shen LP, Bell GI, Rutter WJ \& Shows TB 1983 Polymorphic human somatostatin gene is located on chromosome 3. PNAS 80 2686-2689. (doi:10.1073/pnas.80.9.2686)

Neto LV, Machado Ede O, Luque RM, Taboada GF, Marcondes JB, Chimelli LM, Quintella LP, Niemeyer P Jr, de Carvalho DP, Kineman $\mathrm{RD}$, et al. 2009 Expression analysis of dopamine receptor subtypes in normal human pituitaries, nonfunctioning pituitary adenomas and somatotropinomas, and the association between dopamine and somatostatin receptors with clinical response to octreotide-LAR in acromegaly. Journal of Clinical Endocrinology and Metabolism 94 1931-1937. (doi:10.1210/jc.2008-1826)

Noh TW, Jeong HJ, Lee MK, Kim TS, Kim SH \& Lee EJ 2009 Predicting recurrence of nonfunctioning pituitary adenomas. Journal of Clinical Endocrinology and Metabolism 94 4406-4413. (doi:10.1210/jc.2009-0471)

Obari A, Sano T, Ohyama K, Kudo E, Qian ZR, Yoneda A, Rayhan N, Mustafizur Rahman M \& Yamada S 2008 Clinicopathological features of growth hormone-producing pituitary adenomas: difference among various types defined by cytokeratin distribution pattern including a transitional form. Endocrine Pathology 19 82-91. (doi:10.1007/s12022008-9029-z)

Oberg K \& Lamberts SW 2016 Somatostatin analogues in acromegaly and gastroenteropancreatic neuroendocrine tumours: past, present and future. Endocrine-Related Cancer 23 R551-R566. (doi:10.1530/ERC16-0151)

Olias G, Viollet C, Kusserow H, Epelbaum J \& Meyerhof W 2004 Regulation and function of somatostatin receptors. Journal of Neurochemistry 89 1057-1091. (doi:10.1111/j.14714159.2004.02402.x)

Ooi GT, Tawadros N \& Escalona RM 2004 Pituitary cell lines and their endocrine applications. Molecular and Cellular Endocrinology 228 1-21. (doi:10.1016/j.mce.2004.07.018)

Oriola J, Lucas T, Halperin I, Mora M, Perales MJ, Alvarez-Escola C, Paz de MN, Diaz Soto G, Salinas I, Julian MT, et al. 2013 Germline mutations of AIP gene in somatotropinomas resistant to somatostatin analogues. European Journal of Endocrinology 168 9-13. (doi:10.1530/EJE-12-0457)

Osamura RY, Kajiya H, Takei M, Egashira N, Tobita M, Takekoshi S \& Teramoto A 2008 Pathology of the human pituitary adenomas. Histochemistry and Cell Biology 130 495-507. (doi:10.1007/s00418008-0472-1)

Ostrom QT, Gittleman H, Fulop J, Liu M, Blanda R, Kromer C, Wolinsky Y, Kruchko C \& Barnholtz-Sloan JS 2015 CBTRUS Statistical Report: primary brain and central nervous system tumors diagnosed in the United States in 2008-2012. Neuro-Oncology 17 (Supplement 4) iv1-iv62. (doi:10.1093/neuonc/nov189)

Pages P, Benali N, Saint-Laurent N, Esteve JP, Schally AV, Tkaczuk J, Vaysse N, Susini C \& Buscail L 1999 sst2 somatostatin receptor mediates cell cycle arrest and induction of p27(Kip1). Evidence for the role of SHP-1. Journal of Biological Chemistry 274 15186-15193. (doi:10.1074/jbc.274.21.15186)

Pagotto U, Arzberger T, Ciani E, Lezoualc'h F, Pilon C, Journot L, Spengler D \& Stalla GK 1999 Inhibition of Zac1, a new gene differentially expressed in the anterior pituitary, increases cell proliferation. Endocrinology 140 987-996. (doi:10.1210/ endo.140.2.6532)

Pagotto U, Arzberger T, Theodoropoulou M, Grubler Y, Pantaloni C, Saeger W, Losa M, Journot L, Stalla GK \& Spengler D 2000 The expression of the antiproliferative gene ZAC is lost or highly reduced

Published by Bioscientifica Ltd. 
in nonfunctioning pituitary adenomas. Cancer Research 60 6794-6799.

Patel YC 1999 Somatostatin and its receptor family. Frontiers in Neuroendocrinology 20 157-198. (doi:10.1006/frne.1999.0183)

Patel YC \& Wheatley T 1983 In vivo and in vitro plasma disappearance and metabolism of somatostatin-28 and somatostatin-14 in the rat. Endocrinology 112 220-225. (doi:10.1210/endo-112-1-220)

Peverelli E, Busnelli M, Vitali E, Giardino E, Gales C, Lania AG, Beck-Peccoz P, Chini B, Mantovani G \& Spada A 2013 Specific roles of $\mathrm{G}(\mathrm{i})$ protein family members revealed by dissecting SST5 coupling in human pituitary cells. Journal of Cell Science 126 638-644. (doi:10.1242/jcs.116434)

Peverelli E, Treppiedi D, Giardino E, Vitali E, Lania AG \& Mantovani G 2015 Dopamine and somatostatin analogues resistance of pituitary tumors: focus on cytoskeleton involvement. Frontiers in Endocrinology 6 187. (doi:10.3389/fendo.2015.00187)

Pfeiffer M, Koch T, Schroder H, Laugsch M, Hollt V \& Schulz S 2002 Heterodimerization of somatostatin and opioid receptors crossmodulates phosphorylation, internalization, and desensitization. Journal of Biological Chemistry 277 19762-19772. (doi:10.1074/jbc. M110373200)

Piras G, El Kharroubi A, Kozlov S, Escalante-Alcalde D, Hernandez L, Copeland NG, Gilbert DJ, Jenkins NA \& Stewart CL 2000 Zac1 (Lot1), a potential tumor suppressor gene, and the gene for epsilonsarcoglycan are maternally imprinted genes: identification by a subtractive screen of novel uniparental fibroblast lines. Molecular and Cellular Biology 20 3308-3315. (doi:10.1128/MCB.20.9.33083315.2000)

Potorac I, Petrossians P, Daly AF, Schillo F, Ben Slama C, Nagi S, Sahnoun M, Brue T, Girard N, Chanson P, et al. 2015 Pituitary MRI characteristics in 297 acromegaly patients based on T2-weighted sequences. Endocrine-Related Cancer 22 169-177. (doi:10.1530/ERC14-0305)

Puig Domingo M 2015 Treatment of acromegaly in the era of personalized and predictive medicine. Clinical Endocrinology 83 3-14. (doi:10.1111/cen.12731)

Puig-Domingo M, Resmini E, Gomez-Anson B, Nicolau J, Mora M, Palomera E, Marti C, Halperin I \& Webb SM 2010 Magnetic resonance imaging as a predictor of response to somatostatin analogs in acromegaly after surgical failure. Journal of Clinical Endocrinology and Metabolism 95 4973-4978. (doi:10.1210/jc.2010-0573)

Qian X, Jin L \& Lloyd RV 2000 Aberrant DNA methylation of cyclin D2 and p27 genes in rodent pituitary tumor cell lines correlates with specific gene expression. Endocrine Pathology 11 85-96. (doi:10.1385/ EP:11:1:85)

Reincke M, Sbiera S, Hayakawa A, Theodoropoulou M, Osswald A, Beuschlein F, Meitinger T, Mizuno-Yamasaki E, Kawaguchi K, Saeki Y, et al. 2015 Mutations in the deubiquitinase gene USP8 cause Cushing's disease. Nature Genetics 47 31-38. (doi:10.1038/ng.3166)

Ritvonen E, Pitkanen E, Karppinen A, Vehkavaara S, Demir H, Paetau A, Schalin-Jantti C \& Karhu A 2017 Impact of AIP and inhibitory G protein alpha 2 proteins on clinical features of sporadic GH-secreting pituitary adenomas. European Journal of Endocrinology 176 243-252. (doi:10.1530/EJE-16-0620)

Rocheville M, Lange DC, Kumar U, Patel SC, Patel RC \& Patel YC 2000 Receptors for dopamine and somatostatin: formation of heterooligomers with enhanced functional activity. Science 288 154-157. (doi:10.1126/science.288.5463.154)

Rohrer SP, Birzin ET, Mosley RT, Berk SC, Hutchins SM, Shen DM, Xiong Y, Hayes EC, Parmar RM, Foor F, et al. 1998 Rapid identification of subtype-selective agonists of the somatostatin receptor through combinatorial chemistry. Science 282 737-740. (doi:10.1126/ science.282.5389.737)

Sapochnik M, Nieto LE, Fuertes M \& Arzt E 2016 Molecular mechanisms underlying pituitary pathogenesis. Biochemical Genetics 54 107-119. (doi:10.1007/s10528-015-9709-6)
Saveanu A, Gunz G, Dufour H, Caron P, Fina F, Ouafik L, Culler MD, Moreau JP, Enjalbert A \& Jaquet P 2001 Bim-23244, a somatostatin receptor subtype 2 - and 5 -selective analog with enhanced efficacy in suppressing growth hormone $(\mathrm{GH})$ from octreotide-resistant human GH-secreting adenomas. Journal of Clinical Endocrinology and Metabolism 86 140-145. (doi:10.1210/jcem.86.1.7099)

Saveanu A, Lavaque E, Gunz G, Barlier A, Kim S, Taylor JE, Culler MD, Enjalbert A \& Jaquet P 2002 Demonstration of enhanced potency of a chimeric somatostatin-dopamine molecule, BIM-23A387, in suppressing growth hormone and prolactin secretion from human pituitary somatotroph adenoma cells. Journal of Clinical Endocrinology and Metabolism 87 5545-5552. (doi:10.1210/jc.2002-020934)

Saveanu A, Gunz G, Guillen S, Dufour H, Culler MD \& Jaquet P 2006 Somatostatin and dopamine-somatostatin multiple ligands directed towards somatostatin and dopamine receptors in pituitary adenomas. Neuroendocrinology 83 258-263. (doi:10.1159/000095536)

Schally AV, Huang WY, Chang RC, Arimura A, Redding TW, Millar RP, Hunkapiller MW \& Hood LE 1980 Isolation and structure of pro-somatostatin: a putative somatostatin precursor from pig hypothalamus. PNAS $\mathbf{7 7}$ 4489-4493. (doi:10.1073/pnas.77.8.4489)

Schettini G 1991 Brain somatostatin: receptor-coupled transducing mechanisms and role in cognitive functions. Pharmacological Research 23 203-215. (doi:10.1016/S1043-6618(05)80080-5)

Schonbrunn A \& Tashjian H Jr 1978 Characterization of functional receptors for somatostatin in rat pituitary cells in culture. Journal of Biological Chemistry 253 6473-6483.

Schopf FH, Biebl MM \& Buchner J 2017 The HSP90 chaperone machinery. Nature Reviews: Molecular Cell Biology 18 345-360. (doi:10.1038/ nrm.2017.20)

Sharma K, Patel YC \& Srikant CB 1996 Subtype-selective induction of wild-type p53 and apoptosis, but not cell cycle arrest, by human somatostatin receptor 3. Molecular Endocrinology 10 1688-1696.

Shen LP \& Rutter WJ 1984 Sequence of the human somatostatin I gene. Science 224 168-171. (doi:10.1126/science.6142531)

Shen LP, Pictet RL \& Rutter WJ 1982 Human somatostatin I: sequence of the cDNA. PNAS 79 4575-4579. (doi:10.1073/pnas.79.15.4575)

Shen M, Zhang Q, Liu W, Wang M, Zhu J, Ma Z, He W, Li S, Shou X, Li Y, et al. 2016 Predictive value of T2 relative signal intensity for response to somatostatin analogs in newly diagnosed acromegaly. Neuroradiology 58 1057-1065. (doi:10.1007/s00234-016-1728-4)

Shimon I, Taylor JE, Dong JZ, Bitonte RA, Kim S, Morgan B, Coy DH, Culler MD \& Melmed S 1997a Somatostatin receptor subtype specificity in human fetal pituitary cultures. Differential role of SSTR2 and SSTR5 for growth hormone, thyroid-stimulating hormone, and prolactin regulation. Journal of Clinical Investigation 99 789-798. (doi:10.1172/JCI119225)

Shimon I, Yan X, Taylor JE, Weiss MH, Culler MD \& Melmed S $1997 b$ Somatostatin receptor (SSTR) subtype-selective analogues differentially suppress in vitro growth hormone and prolactin in human pituitary adenomas. Novel potential therapy for functional pituitary tumors. Journal of Clinical Investigation 100 2386-2392. (doi:10.1172/JCI119779)

Shpakov AO 2012 Somatostatin receptors and signaling cascades coupled to them. Zhurnal Evoliutsionnoi Biokhimii i Fiziologii 48 329-341. (doi:10.1134/S0022093012040020)

Somvanshi RK \& Kumar U 2014 delta-opioid receptor and somatostatin receptor-4 heterodimerization: possible implications in modulation of pain associated signaling. PLOS ONE 9 e85193. (doi:10.1371/journal. pone.0085193)

Spada A, Arosio M, Bochicchio D, Bazzoni N, Vallar L, Bassetti M \& Faglia G 1990 Clinical, biochemical, and morphological correlates in patients bearing growth hormone-secreting pituitary tumors with or without constitutively active adenylyl cyclase. Journal of Clinical Endocrinology and Metabolism 71 1421-1426. (doi:10.1210/jcem-716-1421) 
Spengler D, Villalba M, Hoffmann A, Pantaloni C, Houssami S, Bockaert J \& Journot L 1997 Regulation of apoptosis and cell cycle arrest by Zac1, a novel zinc finger protein expressed in the pituitary gland and the brain. EMBO Journal 16 2814-2825. (doi:10.1093/ emboj/16.10.2814)

Suliman M, Jenkins R, Ross R, Powell T, Battersby R \& Cullen DR 1999 Long-term treatment of acromegaly with the somatostatin analogue SR-lanreotide. Journal of Endocrinological Investigation 22 409-418. (doi:10.1007/BF03343583)

Taboada GF, Luque RM, Bastos W, Guimaraes RF, Marcondes JB, Chimelli LM, Fontes R, Mata PJ, Filho PN, Carvalho DP, et al. 2007 Quantitative analysis of somatostatin receptor subtype (SSTR1-5) gene expression levels in somatotropinomas and non-functioning pituitary adenomas. European Journal of Endocrinology 156 65-74. (doi:10.1530/eje.1.02313)

Taboada GF, Luque RM, Neto LV, Machado Ede O, Sbaffi BC, Domingues RC, Marcondes JB, Chimelli LM, Fontes R, Niemeyer P, et al. 2008 Quantitative analysis of somatostatin receptor subtypes (1-5) gene expression levels in somatotropinomas and correlation to in vivo hormonal and tumor volume responses to treatment with octreotide LAR. European Journal of Endocrinology 158 295-303. (doi:10.1530/ EJE-07-0562)

Taboada GF, Neto LV, Luque RM, Córdoba-Chacón J, de Oliveira Machado E, de Carvalho DP, Kineman RD \& Gadelha MR 2011 Impact of gsp oncogene on the mRNA content for somatostatin and dopamine receptors in human somatotropinomas. Neuroendocrinology 93 40-47. (doi:10.1159/000322040)

Taipale M, Jarosz DF \& Lindquist S 2010 HSP90 at the hub of protein homeostasis: emerging mechanistic insights. Nature Reviews: Molecular Cell Biology 11 515-528. (doi:10.1038/nrm2918)

Tateno T, Kato M, Tani Y, Oyama K, Yamada S \& Hirata Y 2009 Differential expression of somatostatin and dopamine receptor subtype genes in adrenocorticotropin (ACTH)-secreting pituitary tumors and silent corticotroph adenomas. Endocrine Journal 56 579-584. (doi:10.1507/endocrj.K08E-186)

Taylor JE, Bogden AE, Moreau JP \& Coy DH 1988 In vitro and in vivo inhibition of human small cell lung carcinoma (NCI-H69) growth by a somatostatin analogue. Biochemical and Biophysical Research Communications 153 81-86. (doi:10.1016/S0006-291X(88)81192-6)

Theodoropoulou M \& Stalla GK 2013 Somatostatin receptors: from signaling to clinical practice. Frontiers in Neuroendocrinology 34 228-252. (doi:10.1016/j.yfrne.2013.07.005)

Theodoropoulou M, Zhang J, Laupheimer S, Paez-Pereda M, Erneux C, Florio T, Pagotto U \& Stalla GK 2006 Octreotide, a somatostatin analogue, mediates its antiproliferative action in pituitary tumor cells by altering phosphatidylinositol 3-kinase signaling and inducing Zac1 expression. Cancer Research 66 1576-1582. (doi:10.1158/0008-5472. CAN-05-1189)

Theodoropoulou M, Tichomirowa MA, Sievers C, Yassouridis A, Arzberger T, Hougrand O, Deprez M, Daly AF, Petrossians P, Pagotto U, et al. 2009 Tumor ZAC1 expression is associated with the response to somatostatin analog therapy in patients with acromegaly. International Journal of Cancer 125 2122-2126. (doi:10.1002/ijc.24602)

Theodoropoulou M, Stalla GK \& Spengler D 2010 ZAC1 target genes and pituitary tumorigenesis. Molecular and Cellular Endocrinology 326 60-65. (doi:10.1016/j.mce.2010.01.033)

Thodou E, Kontogeorgos G, Theodossiou D \& Pateraki M 2006 Mapping of somatostatin receptor types in GH or/and PRL producing pituitary adenomas. Journal of Clinical Pathology 59 274-279. (doi:10.1136/ jcp.2005.026914)

Trivellin G \& Korbonits M 2011 AIP and its interacting partners. Journal of Endocrinology 210 137-155. (doi:10.1530/JOE-11-0054)

Trivellin G, Butz H, Delhove J, Igreja S, Chahal HS, Zivkovic V, McKay T, Patocs A, Grossman AB \& Korbonits M 2012 MicroRNA miR-107 is overexpressed in pituitary adenomas and inhibits the expression of aryl hydrocarbon receptor-interacting protein in vitro. American
Journal of Physiology: Endocrinology and Metabolism 303 E708-E719. (doi:10.1152/ajpendo.00546.2011)

Trivellin G, Daly AF, Faucz FR, Yuan B, Rostomyan L, Larco DO, Schernthaner-Reiter MH, Szarek E, Leal LF, Caberg JH, et al. 2014 Gigantism and acromegaly due to Xq26 microduplications and GPR101 mutation. New England Journal of Medicine $3712363-2374$. (doi:10.1056/NEJMoa1408028)

Trivellin G, Bjelobaba I, Daly AF, Larco DO, Palmeira L, Faucz FR, Thiry A, Leal LF, Rostomyan L, Quezado M, et al. 2016 Characterization of GPR101 transcript structure and expression patterns. Journal of Molecular Endocrinology 57 97-111. (doi:10.1530/JME-16-0045)

Tulipano G, Stumm R, Pfeiffer M, Kreienkamp HJ, Hollt V \& Schulz S 2004 Differential beta-arrestin trafficking and endosomal sorting of somatostatin receptor subtypes. Journal of Biological Chemistry 279 21374-21382. (doi:10.1074/jbc.M313522200)

Tuominen I, Heliovaara E, Raitila A, Rautiainen MR, Mehine M, Katainen R, Donner I, Aittomaki V, Lehtonen HJ, Ahlsten M, et al. 2015 AIP inactivation leads to pituitary tumorigenesis through defective Galphai-cAMP signaling. Oncogene 34 1174-1184. (doi:10.1038/onc.2014.50)

Valente T \& Auladell C 2001 Expression pattern of Zac1 mouse gene, a new zinc-finger protein that regulates apoptosis and cellular cycle arrest, in both adult brain and along development. Mechanisms of Development 108 207-211. (doi:10.1016/S0925-4773(01)00492-0)

Valente T, Junyent F \& Auladell C 2005 Zac1 is expressed in progenitor/stem cells of the neuroectoderm and mesoderm during embryogenesis: differential phenotype of the Zac1-expressing cells during development. Developmental Dynamics 233 667-679. (doi:10.1002/dvdy.20373)

van der Pas R, Feelders RA, Gatto F, de Bruin C, Pereira AM, van Koetsveld PM, Sprij-Mooij DM, Waaijers AM, Dogan F, Schulz S, et al. 2013 Preoperative normalization of cortisol levels in Cushing's disease after medical treatment: consequences for somatostatin and dopamine receptor subtype expression and in vitro response to somatostatin analogs and dopamine agonists. Journal of Clinical Endocrinology and Metabolism 98 E1880-E1890. (doi:10.1210/jc.2013-1987)

van Varsseveld NC, Bisschop PH, Biermasz NR, Pereira AM, Fliers E \& Drent ML 2014 A long-term follow-up study of eighteen patients with thyrotrophin-secreting pituitary adenomas. Clinical Endocrinology 80 395-402. (doi:10.1111/cen.12290)

Varrault A, Ciani E, Apiou F, Bilanges B, Hoffmann A, Pantaloni C, Bockaert J, Spengler D \& Journot L 1998 hZAC encodes a zinc finger protein with antiproliferative properties and maps to a chromosomal region frequently lost in cancer. PNAS 95 8835-8840. (doi:10.1073/ pnas.95.15.8835)

Varrault A, Gueydan C, Delalbre A, Bellmann A, Houssami S, Aknin C, Severac D, Chotard L, Kahli M, Le Digarcher A, et al. 2006 Zac1 regulates an imprinted gene network critically involved in the control of embryonic growth. Developmental Cell 11 711-722. (doi:10.1016/j. devcel.2006.09.003)

Vieria Neto L, Wildemberg LE, Colli LM, Kasuki L, Marques NV, Moraes AB, Gasparetto EL, Takiya CM, Castro M \& Gadelha MR 2013 ZAC1 and SSTR2 are downregulated in non-functioning pituitary adenomas but not in somatotropinomas. PLOS ONE 8 e77406. (doi:10.1371/ journal.pone.0077406)

Vierimaa O, Georgitsi M, Lehtonen R, Vahteristo P, Kokko A, Raitila A, Tuppurainen K, Ebeling TM, Salmela PI, Paschke R, et al. 2006 Pituitary adenoma predisposition caused by germline mutations in the AIP gene. Science 312 1228-1230. (doi:10.1126/science.1126100)

Wang L, Huang X, Chai Y, Zou L, Chedrawe M \& Ding Y 2017 Octreotide inhibits the proliferation of gastric cancer cells through P300-HAT activity and the interaction of ZAC and P300. Oncology Reports $\mathbf{3 7}$ 2041-2048. (doi:10.3892/or.2017.5451)

War SA, Kim B \& Kumar U 2015 Human somatostatin receptor-3 distinctively induces apoptosis in MCF-7 and cell cycle arrest in http://joe.endocrinology-journals.org

DOI: $10.1530 / \mathrm{JOE}-17-0254$
๑ 2017 Society for Endocrinology Printed in Great Britain 
MDA-MB-231 breast cancer cells. Molecular and Cellular Endocrinology 413 129-144. (doi:10.1016/j.mce.2015.06.019)

Wildemberg LE, Neto LV, Costa DF, Nasciuti LE, Takiya CM, Alves LM, Rebora A, Minuto F, Ferone D \& Gadelha MR 2013 Low somatostatin receptor subtype 2 , but not dopamine receptor subtype 2 expression predicts the lack of biochemical response of somatotropinomas to treatment with somatostatin analogs. Journal of Endocrinological Investigation 36 38-43. (doi:10.3275/8305)

Yang I, Park S, Ryu M, Woo J, Kim S, Kim J, Kim Y \& Choi Y 1996 Characteristics of gsp-positive growth hormone-secreting pituitary tumors in Korean acromegalic patients. European Journal of Endocrinology 134 720-726. (doi:10.1530/eje.0.1340720)

Yoshihara A, Isozaki O, Hizuka N, Nozoe Y, Harada C, Ono M, Kawamata T, Kubo O, Hori T \& Takano K 2007 Expression of type 5 somatostatin receptor in TSH-secreting pituitary adenomas: a possible marker for predicting long-term response to octreotide therapy. Endocrine Journal 54 133-138. (doi:10.1507/endocrj.K06-133)

Zatelli MC, Piccin D, Tagliati F, Ambrosio MR, Margutti A, Padovani R, Scanarini M, Culler MD \& degli Uberti EC 2003 Somatostatin receptor subtype 1 selective activation in human growth hormone (GH)- and prolactin (PRL)-secreting pituitary adenomas: effects on cell viability, GH, and PRL secretion. Journal of Clinical Endocrinology and Metabolism 88 2797-2802. (doi:10.1210/jc.2002-021825)

Zatelli MC, Piccin D, Bottoni A, Ambrosio MR, Margutti A, Padovani R, Scanarini M, Taylor JE, Culler MD, Cavazzini L, et al. 2004 Evidence for differential effects of selective somatostatin receptor subtype agonists on alpha-subunit and chromogranin a secretion and on cell viability in human nonfunctioning pituitary adenomas in vitro. Journal of Clinical Endocrinology and Metabolism 89 5181-5188. (doi:10.1210/jc.2003-031954)

Zatelli MC, Piccin D, Tagliati F, Bottoni A, Ambrosio MR, Margutti A, Scanarini M, Bondanelli M, Culler MD \& degli Uberti EC 2005 Dopamine receptor subtype 2 and somatostatin receptor subtype 5 expression influences somatostatin analogs effects on human somatotroph pituitary adenomas in vitro. Journal of Molecular Endocrinology 35 333-341. (doi:10.1677/jme.1.01876)

Zatelli MC, Piccin D, Tagliati F, Bottoni A, Luchin A, Vignali C, Margutti A, Bondanelli M, Pansini GC, Pelizzo MR, et al. 2006 Selective activation of somatostatin receptor subtypes differentially modulates secretion and viability in human medullary thyroid carcinoma primary cultures: potential clinical perspectives. Journal of Clinical Endocrinology and Metabolism 91 2218-2224. (doi:10.1210/ jc.2006-0334)

Zatelli MC, Piccin D, Vignali C, Tagliati F, Ambrosio MR, Bondanelli M, Cimino V, Bianchi A, Schmid HA, Scanarini M, et al. 2007 Pasireotide, a multiple somatostatin receptor subtypes ligand, reduces cell viability in non-functioning pituitary adenomas by inhibiting vascular endothelial growth factor secretion. Endocrine-Related Cancer 14 91-102. (doi:10.1677/ERC-06-0026)

Zhou G, Liu SH, Shahi KM, Wang H, Duan X, Lin X, Feng XH, Li M, Fisher WE, Demayo FJ, et al. 2012 Negative regulation of pancreatic and duodenal homeobox-1 by somatostatin receptor subtype 5. Molecular Endocrinology 26 1225-1234. (doi:10.1210/ me.2012-1095)

Received in final form 25 July 2017

Accepted 22 August 2017

Accepted Preprint published online 23 August 2017
C 2017 Society for Endocrinology Printed in Great Britain 